\title{
EXTRACTION OF COLLAGEN THROUGH FISH WASTE FERMENTATION OPTIMIZATION AND ITS CYTOTOXIC STUDIES ON HaCaT CELL LINE
}

\author{
S M Nazmuz Sakib \\ Graduate of BSc in Business Studies \\ School of Business And Trade \\ Pilatusstrasse 6003, 6003 Luzern, Switzerland \\ sakibpedia@gmail.com \\ Student of Department of Law \\ Dhaka International University \\ House \# 4, Road \# 1, Block - F, Dhaka 1213 \\ sakibpedia@students.diu.ac
}

\begin{abstract}
More than 800 million tons of fish are utilizing in a year and 25-30\% become waste. The waste amount is beneficial source for extraction of collagen. But procedure of extraction is still to be optimized. The current study was designed to extract collagen from fish through fish waste fermentation under various conditions. For collagen extraction we did lactic acid fermentation in which yogurt and Dough bacteria was added with fish sample and placed it in incubator at $30^{\circ} \mathrm{C}$ for one month. In yogurt and dough culture have at least 10 type of lactic acid bacterial species. After every week we check PH of each sample and take soup of that sample. After centrifugation of that sample's TCA (Trichloroacetic acid) precipitation was done of yogurt and dough sample and kept at $-20^{\circ} \mathrm{C}$. then did SDS-PAGE) using 6\% resolving and 5\% stacking gel of already stored sample. Then HaCaT cells $\left(1 \times 10^{4}\right.$ cells/well $)$ were cultured in 96-well flat-bottom culture plates and treated with appropriate doses of FFCP (fermented fish collagen peptide) for 24 and 48 hours.

The SDS-PAGE revealed that the collagen protein of fish had doublet pattern for $\alpha 1$ and $\alpha 2$ chains at corresponding to $145 \mathrm{kDa}$ and $132 \mathrm{kDa}$ respectively. The density for $\alpha 1$ twice as compared to $\alpha 2$. Our result agrees that The fish collagen consists mostly of $\alpha$-chain as well as little amount of
\end{abstract}


inter and intra molecular cross-linked components of $\alpha$-chains; $b$ (dimmer) and c (trimer). Different biochemical tests were done for identification of lactic acid bacteria catalase positive, citrate positive, urease negative. Our fermented fish collagen and peptides mixture were test for cellular cytotoxicity and proliferative effect on $\mathrm{HaCaT}$ cells. Current result shows that fermented extracted collagen are nontoxic and induce the proliferation of HaCaT cells. Current study is supported by various studies that revealed the medical application of fish extracted collagen as underline.

Keywords: Collagen, Environment, Fish Waste, Cytotoxic, Fermentation

\section{LIST OF ABRIVIATIONS}

TSE

BSE

FFCP

Ala

Pro

Gly

CNS

PrPsc

LAF

LAB

DO

HS

DW

TCA

SDS

PAGE

TSI
Transmissible spongiform encephalopathy

Bovine spongiform encephalopathy

Fermented fish collagen peptide
Alanine
proline
Glycine

Central nervous system

pathological prion protein

Lactic acid fermentation

Lactic acid Bacteria

Dissolved Oxygen

Hestrin-Schramm Media

Distilled water

Trichloroacetic acid

Sodium dodecyl Sulphate

poly acrylamide gel electrophoresis

Triple sugar Iron 


\section{INTRODUCTION}

\section{1: COLLAGEN}

Collagen is the most abundant protein on earth and it contains $25-35 \%$ of the total body protein of animal's body. Collagen protein makes up the main constituent of bone and skin in animals and the collagen provide a glue as connective protein. In connective tissue of animal, the main structural protein is collagen. (Gelse et al., 2003; Singh et al., 2011). The recent era explored the use of collagen protein in various industries such as in pharmaceutical, biomedical, cosmetic, film and leather industries. (Gelse et al., 2003; Ogawa et al., 2004). The collagen protein is produced by plant, animal and fish at industrial level. But fish collagen protein provides several advantages over plant sources and animal sources protein (Subhan et al., 2015).

The fish collagen is considered more valuable for use in biomedical as well as other health industries. In comparison of land animal collagen application, infectious diseases like transmissible spongiform encephalopathy (TSE), bovine spongiform encephalopathy (BSE) and mouth and foot diseases are not likely to be linked with fish collagen. Thus, wastes of fish are alternate source of collagen production (Jongjareonrak et al., 2005; Nagai et al., 2001).soluble form of collagens is beneficial in different fields like cosmetics, food and medicines due to its special features for example week antigenicity and biodegradability (Kołodziejska et al., 1999). Due to its physical and chemical properties of fish collagen are completely change from animal collagen (Zhang et al., 2007). Recently, only chemical and enzymatic method is used for extraction of fish collagen which are either might be toxic due to use of toxic chemicals for extraction or expensive due to use of expensive enzymes for extraction (da Rosa Zavareze et al., 2010). Hence, the goals of this study are to find safe and cheap biological method for extraction of collagen protein from fish wastes and to characterize and apply in biomedical field such as skin care and protection.

\section{2: EXTRACTION OF COLLAGEN}

Chemical hydrolysis and enzymatic hydrolysis can be used for collagen obtaining (Zavareze et al., 2009). Recently chemical extraction method for collagen is mostly used while in addition the use of enzymes is considered more nutritional but still there is requirement of an alternate procedure to extract collagen (Martins et al., 2009). Additionally, less waste is produced by enzymatic 
method and have short time interval but this process is very expensive. The chemical procedure comprises of the pretreatment use which is performed before the extraction of collagen may be extracted utilizing an acidic or basic process, that differs with respect to raw material origin. For the purpose of removing non collagenous substances and to get more yields pretreatment method can be utilized (Schmidt et al., 2016). For the purpose of collagen extraction, the most commonly used methods are based on the solubility of collagen in neutral saline solutions, acidic solutions and acidic solutions with added enzymes (Schmidt et al., 2016). Many known methods for extracting collagen, each method has its own limitations. Many efforts are focused to obtain collagen with high purity, high yield, reserved structural integrity and its unique properties including gel formation capabilities, water retention and thermal stability (Schmidt et al., 2016). The acid base simplified method of collagen extraction.

\subsection{1: Pre-Treatment:}

Because of naturally cross-linking collagen in the connective tissues of animals' dissolves very slow, even in hot water. Small amount of chemical treatment is also needed to break crosslinks before extraction. (Schrieber and Gareis, 2007). In the end, the acids that is diluted and employed bases and collagen that is exposed to semi hydrolysis, that keeps the chains of collagen unbroken while crosslinks are cut into pieces. In pretreatment acidic form the waste materials are immersed in acidic solution till entry of solution by the substance. At a controlled temperature as the solution enters the skin structure it swells to two or three times of its actual volume and the breaking of the non-covalent inter and intra-molecular bonds occurs (Ledward, 2000). Acidic process is more suitable for more fragile raw materials with less intertwined collagen fibers, for example fish skins and porcine (Fernandes de Almeida et al., 2012). This procedure is used to thicker substances which need most energetic entry through the use treatment agents, like, bovine ossein or shavings(Ledward, 2000). Sodium hydroxide and calcium hydroxide are commonly utilized for the purpose of pre-treatment, however sodium hydroxide is more suitable for pre-treatment of the skins because it causes significant swelling, which promotes collagen extraction by increasing exchange rate of the mass in the tissue matrix (Liu et al., 2015). 


\subsection{2: Chemical hydrolysis}

Organic acids like citric acid, lactic acid and acetic acid and inorganic acids like hydrochloric acid are used for acid hydrolysis. Though, organic acids have observed more effective compare to inorganic acids (Liu et al., 2015; Skierka and Sadowska, 2007). The non-cross linked can be dissolve by organic acids and also the inter-strand cross-liked in collagen can be break by it; which the very high solubility of collagen at the time of extraction process (Liu et al., 2015). Hence for the extraction of collagen acid solution, particularly acetic acid is used commonly. The pretreatment materials has to be added to the acid solution in order to extract acid soluble collagen, those could be $0.5 \mathrm{M}$ acetic acid and should be hold under continuously stirring at $4 \mathrm{C}^{\circ}$ for $24-72$ hours depending on the type of raw material (Kaewdang et al., 2014; Liu et al., 2015; Nagai et al., 2000).

Filtering process is needed to isolate supernatant from the collagen after the extraction process, which has state of liquid. After that the filtrate is precipitated with $\mathrm{NaCl}$ to get the collagen powder. Centrifugation has to be used to collect the precipitate and later on it could be re-dissolve in minimum volume of $0.5 \mathrm{M}$ acetic acid and then dialyzed in 0.1 acetic acid for 48 hours, and then distilled water are applied for 2 days, with replacement of the solution on average every 12 hours (Schmidt et al., 2016).

\subsection{3: Enzymatic hydrolysis:}

There is strong intermolecular covalent bond in telopeptide region of triple helix structure in collagen, which cannot be sliced by using only acetic acid which specifies enzymes like pepsin from fishes, mammalian, trypsin, papain, alkaline protease, bromelain collagenase etc. which is added to remove non-helical structures by increasing collagen solubility. Out of all these, most utilized enzyme for marine collagen extraction is pepsin (Ehrlich et al., 2010; Silva et al., 2014). The triple helix structure is maintained by whole isolated collagen, specially collagen type I having same shape and amino acids arrangement.

The triple helix structure maintains in all extracted collagen, as the amino acid profile and similar morphology of type I collagen. Chemical analysis shows less points of interest as compared to spectral analysis of enzymatic analysis, e.g. specificity, degree control of hydrolysis, low level of 
actions, and in last hydrolysate lower salt contents. Additionally, enzymes have vey less use and there is no need to remove these enzymes from medium (Zavareze et al., 2009).

\section{3: CONSTITUENTS OF COLLAGEN}

Main protein present in skin and other connective tissue, which is present in different forms in all tissues of multicellular organisms. It performs different roles based on its position (Schmidt et al., 2016). From different species of animals, we can extract collagen and it is commonly from meat by-products. Bones, skin, tendons, and cartilage are important sources of collagen. Several other studies suggest that collagen can also be extracted from sources other than animals like birds and fish as substitute to bovine collagen from that has risk of bovine spongiform encephalopathy(Kaewdang et al., 2014; Wang et al., 2014).

The sharing of structure, composition and molar mass, and the consequent active structures and characteristics of collagen, rely on processing situations of that substances from which it is taken and the enzyme specificity used in the process of extraction.(Schmidt et al., 2016). Therefore, it's important to keep in limit process of extraction for every raw substance to get good reward and high collagen characteristics for the preferred use. Collagen can be used as industrial application because it is one of the best biomaterial due to its broad variety (Schmidt et al., 2016). In food industry collagen and gelatin has very high demand due to high content of protein and their handy stuffs, like gel formation, formation of stabilize emulsion ability and water absorption capacity. Collagen can be used as transporter for drugs, genes and proteins and also used for human skin, blood vessels and ligaments as substitute(Gómez-Guillén et al., 2011; Kim and Mendis, 2006).

Collagen protein is present in every multicellular animals (Schmidt et al., 2016). In vertebrates and invertebrates' collagen is an essential factor in the support structures. In mammals' collagen found most abundantly resulting of about $25 \%$ of the total weight of all protein (Badii and Howell, 2006; Schmidt et al., 2016), and it is the essential protein of cartilage, bones, tendons tissues and skin particularly. Collagen in fishes and poultry play the same role as an invertebrates and is the essential constituent of the body wall(Badii and Howell, 2006).

In mammals have many type of collagen which contain typically of about $11 \%$ alanine (Ala) $21 \%$ proline (Pro), 35\% glycine (Gly) and hydroxyproline. In collagen the amino acid sequence is usually repetitive triple peptide unit (Gly-X-Y), in which $\mathrm{X}$ is mostly Pro and $\mathrm{Y}$ is mostly Hyp 
(Schmidt et al., 2016). Until now about twenty-nine (29) type of collagen have been stated, which are placed based on their structures (Schmidt et al., 2016).

\section{4: STRUCTURE OF COLLAGEN}

Members of every collagen family have same right-handed triple helix which have characteristics of three alpha chain as shown in figure 1 (Lethias et al., 2010) The three identical polypeptide chain (homotrimers) may be creates the right handed triple helix structurally, as in collagen type (II, III, VII, VIII, X) and many others. Though mostly rich collagen types like (I, IV, V, VI, IX, and XI) are heteromers, which are right handed triple helix formed by two or more different heteromeric chains. An extensive left-handed helix which is created by each three $\alpha$-chain and has a pitch of eighteen (18) amino acids per turn (Fallas et al., 2009). The right-handed super helix which are formed by three $\alpha$-chain have one staggered residue arranged and adjacent chain as a common central axis in a right-handed style around by supercoil to make the triple helix structure. The glycine characterizes the triple helical collagenous domain in every $3^{\text {rd }}$ point of polypeptide chain which make a (Gly-X-Y)n duplicate structure. The alpha chain assembled around central point in a way that all glycine residue is positioned in the center of the triple helix, while other amino acids larger chains are located in the outer side. This allowed the peptide chain fold strongly down the central point of the molecule while the steric clashes in the center of the assembly are been avoiding.

The proline and hydroxyproline frequently filled the $\mathrm{X}$ and $\mathrm{Y}$ positions. Depend on collagen type, some lysine and proline residue are altered by post translational enzymatic hydroxylation. For the development of intramolecular hydrogen bonds, the 4-hydroxyproline contents are vital which also helps in the conformation's stability of the triple helical. Between different types of collagen, the length of triple helical parts is different (Fallas et al., 2009; Gelse et al., 2003; Gordon and Hahn, 2010). In fibril forming collagen (I, II, III), with exemption of collagen type XXIV and XXVII, the (Gly-X-Y) replicate in the helix is the main three-layered helical domain. The length of fibril forming collagen are about 1000 amino acids residues and have perfect structure of Gly-X-Y triplet. For non-fibril forming collagen, in the triple helices have at least one interruption (Gordon and Hahn, 2010). N-propetide ore N-peptide is the fibrillar collagen end amino acids. Normally it 
is consisting of about one small triple helical domain called minor helix.

Triple helix
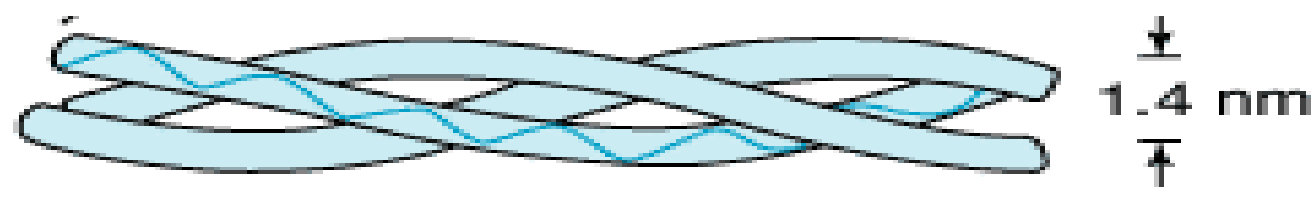

\section{Alpha chailn}

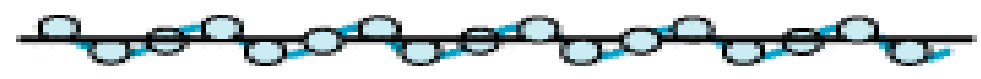

\section{Amino acid sequence}

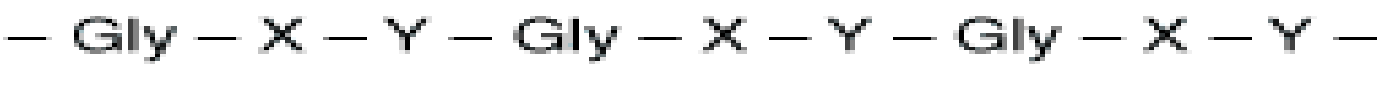

Figure 1.0-1: Molecular structure of a collagen triple helix in type I collagen molecule (Chhabra, 2013)

After the formation of major triple helix, the carboxyl and amino ends are processed. The processed molecule is ranged in a procedure of a quarter stagger in the increasing fibril. Fibrils of type I and type II collagens nucleate respectively by type V and XI collagens (Gordon and Hahn, 2010; Kadler et al., 2008). The N-peptide of collagen V and XI regulate the fibril diameter which are retained after processing (Birk, 2001; Gordon and Hahn, 2010).

\section{5: COMPOSITION OF COLLAGEN}

Collagen peptides of fish have particular composition of amino acids with great content of proline, hydroxyproline and glycine. By ingestion of fish collagen, hydroxyproline peptides are not fully absorbed to free amino acid and in blood it can be detected. In the skin, bones and joints these hydroxyproline stimulate the cells and synthesis collagen by cell growth and activation (Subhan et al., 2015). On age collagen type III intensely depends; mostly young age skin has about 50\% collagen type III but as skin but with age collagen type III percentage can be fallen from 5 to $10 \%$. In animal kingdom there are about twenty (20) different type of collagen. Every mature collagen consists of three polypeptide chain called $\alpha$ chain that might be different or same and are arranged in triple helical structure (Bella 2016). Every $\alpha$ chain can be identified by its nomenclature: $\alpha n(N) p$, $\mathrm{n}$ is the identification number of $\alpha$ chain, $p$ is the number of polypeptide and $N$ is the number of collagen. 
Among organs collagen distribution are different and with type the length of collagen varies. Each polypeptide is $300 \mathrm{~nm}$ long (corresponding to about 1000 AA residues) in type I, II, III collagens (Burgeson and Morris, 1987; CHU et al., 1987). E.g. in type I collagen each of the two identical al(I) chain contain 1056 AA residues. Collagen molecules pack together side by side in fibrous collagen through an interchain cross-link between allysine residues formed by the extracellular lysyl oxidase (Bella, 2016).

\section{6: SOURCES OF COLLAGEN}

The main industrial sources for collagen production are Bovine and porcine skins. In 1930, porcine skin was the first raw material used for collagen production and nowadays porcine skin is still the most significant raw material for large scale industrial production of collagen (Gómez-Guillén et $a l ., 2011)$. It has been reported that collagen of porcine skin has bovine spongiform encephalopathy (BSE), while collagen of fish has such chances of pathogen like BSE(Yamaguchi, 2002).Other than this, Jews and Muslims not accepting any food products related to pigs and Hindus not accepting or consume food products related to cow(Karim and Bhat, 2009b).

By- product from the slaughter of pork and beef are the key sources for collagen extraction (Ferreira da Silva and Barretto Penna, 2012; Jia et al., 2010). Different by products already have been studied including tendon and the Achilles (Li et al., 2009), bovine bones (Paschalis et al., 2001), pericardium(Santos et al., 2013) and inner layer of bovine skin(de Moraes and Cunha, 2013), porcine lung(Lin et al., 2011) and porcine skin (Yang and Shu, 2014). Nowadays it is examined that by product of fish is alternate source for extraction of collagen (Kaewdang et al., 2014; Mahboob, 2015; Muralidharan et al., 2013; Ninan et al., 2014; Tang et al., 2015; Wang et $a l ., 2014$ ). Bovine spongiform encephalopathy (BSE) belongs to family of disease known as transmissible spongiform encephalopathies (TSE), which affected by the increasing of pathological prion protein (PrPSc) in central nervous system (CNS) and brain that affect bovines of adult.

Thus, many researches have keen interest to find an alternative collagen source. For now, collagen of fish waste was found to have the most relevant features to collagen of mammals. Hence, it's important to draw the industry's attention to marine collagen(Kim and Mendis, 2006; Nagai and Suzuki, 2000). 
therefore, many types of species of fish were examined as alternate source of collagen. Studies of all fish showed different denaturation temperature features. Due to this interest among research communities had raised in optimizing the yields and extraction condition and also characterizing the final collagen. These collagens were generally extracted from fish bone, scales and skin residues. Alaska Pollock, Atlantic salmon and Cod are living in cold water and were researched on their functional and physio-chemical properties. Species living in cold water showed significantly low denaturation temperatures (around 4-17 ${ }^{\circ} \mathrm{C}$ ) while tropical species denaturation temperature is (around $18-29^{\circ} \mathrm{C}$ ). sub-tropical species were red Tilapia, channel catfish, yellowfin Tina, skate or grass carp, Nile perch (Gómez-Guillén et al., 2011; Karim and Bhat, 2009b).

In this type of situation collagen of fish are best as it has no risk of transmission of disease, no religious barriers and have high availability. The key difference between animal collagen and fish collagen are high essential amino acids, high biological value and low concentration of hydroxyproline. the fish fins that is waste products of canned tuna processing are high quality collagen source extracted but with low yields (Aewsiri et al., 2008)., Such as bigeye snapper(Kittiphattanabawon et al., 2005; Nalinanon et al., 2007), carp(Duan et al., 2009), threadfin bream(Nalinanon et al., 2008), yellowfin tuna(Woo et al., 2008) etc. have been characterized and extracted. 
Table 1-1: Comparative study between marine and mammalian collagen

\begin{tabular}{|l|l|l|}
\hline S. No & Marine & Mammalian \\
\hline 01 & Low melting point & High melting point \\
\hline 02 & Cheap & Expensive \\
\hline 03 & Easily available (high amount) & Difficult extraction (less amount) \\
\hline 04 & Low viscosity solution & High viscosity solution \\
\hline 05 & No risk of transmitted disease & High risk of transmitted disease \\
\hline 06 & PRO contents of GLX and ALA with low & Low contents of GLX and ALA \\
& Soluble in water & Soluble in organic solvent \\
\hline 07 & & \\
\hline
\end{tabular}

Therefore, more importance has been given to alternate sources of collagen especially from fish bone, skin and scale (Nalinanon et al., 2007; Skierka and Sadowska, 2007; Wang et al., 2007). Fish offal like bones, skin, fins and scales has gain more importance as alternate source of collagen(Gómez-Guillén et al., 2002). From the discarded portion of fish wastes fish collagen can be produced like fins, skin and scales which are rich sources of collagen(Dun et al., 2008).

\section{7: BIOFERMENTATION}

Bio fermentation is a natural procedure that inevitably disturb the food supply of human around the world is fermentation. The word fermentation is a Latin word which mean fervere means to boil, which indicate the presence of yeast action on extract of salted grains or fruits during alcoholic beverages production. For microbiologist fermentation word mean any process which are used for production of different products of mass culture of microorganisms. On the other hand, for a biochemist, fermentation means a process which generating energy and organic compound reacts as both electron donor and acceptor. Fermentation occur in absence of oxygen in which 
energy are produced. (Stanbury et al., 2013). Foods which are produce after the action of microorganism or enzymes are fermented foods due to which significant modification of food and desirable biochemical changes occur.(Campbell-Platt, 1987). Fermentation technology plays an important role in technology of food. Fermented food is accepted throughout the world and rise in the human relation to the microbial world. Fermented foods like beer, wine, bread and yoghurt are mostly used as a food. Microbial ecosystem of fermented foods, like cheese, bread, yoghurt, beer and other foods constitute microbial ecosystem that present in human families throughout the world. Fermented food production doesn't require information of the biologically mediated nature of fermentation, because the biota that do fermentation are present throughout the world, either humans use them or not. The relationship associated with safe foods can be treated as microbial ecosystem, sat at the top of the counter and stored in food sales worldwide. The main ingredients of fermentation ecosystem include: (molds, bacteria and yeast), biological materials which are to be fermented, fermentation solution, a pot developed with a close door and different other resources that is developed can be used to be and fermentation monitoring. Consumed foods are protected by microbes that live in, food storage vessels (Scott and Sullivan, 2008).

Dried foods are counted as all our foods, which are mainly used for meat, milk, soybean, fish and plant products for commercial production. Acute food production is highest in Europe, Africa and North America. America in the south, large amounts of drinks and products of milk are fermented. fermented dairy products in the middle east are important and in the Indian subcontinent grain are fingers in high amount. In Southeast and Eastern Asia, grapes and fish are the most importantly consumed nutrition, both in the source of protein. In these areas, as well as the use of cereals, can be cumulative with fingers that produce soybean in soya and rice or yoghurt production with soybean in wheat. While many yeast food items are used where they are made, there are quantities in alcohol trade, spirits and wine through growing things, and for soy sauce and for fault (Campbell-Platt, 1994).

\section{8: LACTIC ACID FERMENTATION}

Lactic acid bacteria are non-spore forming or coconut, Gram-positive, growing, catalase negative lacking a hem source, generally sessile and rarely nitrate reducer. Glucose has used by them for fermentation and might be also homofermentative, about $85 \%$ lactic acid could be produce by 
them from glucose or heterofermentive generating $\mathrm{CO} 2$, ethanol and acetic acid or lactic acid in the equimolar volume from lactic acid (Dworkin, 2006). Genera lactobacillus strains lactococcus, enterococcus, Aerococcus, Tetragenococcus, Vagococcus, Camobacterium, Pisciglobus created Ilactic acid; several lactobacillus strains and Leuconostoc created d-lactic acid whereas many other lactobacillus, pedicoccus and Weissella strains created dl-lactic acid (König and Fröhlich, 2017; Tanasupawat et al., 2011).

\subsection{1: Condition for lactic acid bacteria (LAB) fermentation:}

The most suitable environment for lactic acid bacteria (LAB) are lower ethanol contents, lower optimum PH, optimum temperature, and enough fermentable sugar contents. Furthermore, both $\mathrm{LAB}$ and yeast are capable to survive under less dissolved oxygen (DO) things due to which condition over turns a growth of aerobic general bacteria (Inoue et al., 2013)

\section{9: FISH FERMENTATION}

The products of marine finfish and fresh water, shellfish and crustaceans can be denoted by fermented fish products which are results due to the joint action of fish enzyme and bacterial enzyme with salt to carry out fermentation and avoid putrefaction (Ruddle and Ishige, 2010; Saisithi, 1994). Textural change produced by the enzymes and helped in flavor production whereas bacteria involved flavor for fish fermentation and developed the aroma (Beddows, 1998). Area which has seasonal plenty of local fish, preservation of fish occurs in those area. Fish species of fresh water certainly found in native hydrological systems have been fermented. First time the process of fermentation was developed amongst sitting farmers and anywhere salt is obtained simply. Fermentation of fish has advanced in local regions of southeast and continental East Asia (Ruddle and Ishige, 2010). In East Asia a widespread range of fermented- fish has created that an exacting grouping by product variety should be restricted to separate states. Method of preparation and end product is key cause for its classification.

fish biomass Effective utilization (fish waste and by-catch fish) is vital. Biomass of fish has recognized rich in different nutritional elements like lipids, minerals and proteins(Council, 2002). Adding with this biomass of fish can easily ruin due to high nutritional content and high moisture. Generally, biomass of fish is preventing from spoil by heat drying and allowed it for utilization. About fish silage production many reports available (Espe and Haaland, 1992; Raa et al., 1982). 
Lactic acid bacteria which are usually found in raw material is used for the biological fermentation of fish waste. It could be carried out by chemical acidification using organic or inorganic acid, or introduced as starter culture (Raa et al., 1982).

Fish fermentation wastes by means of starter cultures with mixture of Lactic acid bacteria (LAB) and yeasts was observed by Faid et al. By biological fermentation fish wastes is processed using a combine starter cultures of Saccharomyces species. and Lactobacillus plantarum to change wastes of fish into stable feed ingredient (Faid et al., 1997). Process of producing of starter of sake (moto), soy sauce, Lactic acid bacteria help to avoid contamination of other bacteria because of a symbiotic relation with koji mold (Aspergillus Niger) and yeast (Saccharomyces cerevisiae) under lower acidity, allowing glucose produced by koji mold. Though in the later stage of the process LAB is known to die due to too much ethanol and acidity and high temperature by fermentation (Inoue et al., 2013).

\subsection{0: PROTEIN ANALYSIS}

\subsection{1: General consideration and classification of protein}

protein is one of the abundant component of all cells, and about all excluding storage proteins are essential for cell structure and biological functions. Protein present in food are very complex. A high number of protein have been characterized and purified. Protein have different molecular mass, of about 5,000 to more than a million Daltons. Protein are consisting of different elements like carbon, hydrogen, oxygen, Sulphur and nitrogen. Building blocks of proteins are $20 \alpha$-amino acids. In proteins amino acids are linked by peptide bonds. The most distinguishing element present in protein is Nitrogen. But in various food proteins nitrogen content ranges from 13.4 to $19.1 \%$ (1) Because of amino acid variation of specific amino acids composition of proteins. Usually basic amino acids rich protein contains more nitrogen.

\subsection{2: Classification of protein}

Protein are classified by their structure, composition, biological function, or solubility properties. E.g. simple protein only consists of amino acids upon hydrolysis, but protein which are conjugated also consist of non-amino acid components. Protein has unique structure that can be change by heat, alkali, acid, $6 M$ guanidine-HCL, $8 M$ urea, detergents and organic solvents. Functional 
properties as well as solubility of protein can be changed by denaturants. Protein analysis is complex because some foods components contains similar physical and chemical properties. Nitrogen which are non-protein could come from amino acids, nucleic acids, peptides, amino sugars, porphyrin, phospholipids, and some vitamins, uric acid, urea, ammonium ions, and alkaloids. That's why organic nitrogen in foods would signify nitrogen initially from proteins and have low extent from all other organic nitrogen which contain non-protein substances. On methodology dependent other main food components, containing carbohydrates and lipids can affect physically with analysis of food protein.

\subsection{1: OBJECTIVES}

- The study will focus to identify the bacteria involved in fish waste fermentation, and the optimization of identified bacteria for production and purification of TypeI collagen.

- To investigate the cytotoxic effect of collagen on HaCaT culture cell line. 


\section{MATERIALS AND METHODS}

\section{1: Study Area}

The current study was designed from July 2017 to August 2018 at Department of Microbiology, Hazara university, Mansehra, KP, Pakistan.

\section{2: Study purpose:}

Study purpose was to do fermentation of fish through lactic acid bacteria for collagen type I extraction.

\section{3: Specimens Collection and Storage}

Siran River is one of the best fishing site and marketing place in District Mansehra that is situated near Hazara University. Fresh fish were collected from the Siran Fishing market in sterile bags and transported instantly to central laboratory at Department of Microbiology, Hazara University Mansehra. The specimens were washed three times and then kept at $4^{\circ} \mathrm{C}$ for 24 hours for further processing.

\section{4: Preparation of HS Media (Hestrin-Schramm Media)}

\section{Ingredients}

- $\quad 20 \mathrm{~g}$ D-glucose

- $\quad 5 \mathrm{~g}$ Peptone

- $\quad 5 \mathrm{~g}$ Yeast Extract

- $\quad 2.7 \mathrm{~g} \mathrm{Na} 2 \mathrm{HPO} 4$

- $\quad$ 1.15g Citric Acid

- $\quad 1000 \mathrm{ml}$ Distilled Water

- $\quad \mathrm{pH} 6.0$ 


\section{Preparation of Media}

○ Vacuum Electronic Balance was used for the measurement of ingredients.

○ The ingredients were mixed with distilled water by stirring.

○ Then autoclaved at $121^{\circ} \mathrm{C}$ for 15 minutes.

○ After cooling $\left(45^{\circ} \mathrm{C}-60{ }^{\circ} \mathrm{C}\right), 2.5 \mathrm{ml}$ of antifungal (Nystatin) was added to the media.

- The media was preserved on room temperature at appropriate environment until further use.

\section{5: Preparation of Agar Plates:}

- $\quad 100 \mathrm{ml}$ of already prepared HS media was poured into flask

- $6 \mathrm{~g}$ of agar was added into the media

- $\quad$ The media was heated on heat stirrer up to gently mixing of agar with media

- $\quad$ The media was remained to cool to be handled easily

- $\quad$ The media was divided into equal concentrations on 10 different sterilized petri plates

- $\quad$ The petri plates were stored at $4{ }^{\circ} \mathrm{C}$.

\subsection{1: Culturing on Petri Plates}

The petri plates were transferred to laminar flow unite.

$>$ Dry dough was diluted in distilled water.

$>$ The diluted dough was streaked on two different petri plates containing HS agar media through sterile swab.

$>$ Similarly, yogurt was also streaked on two different HS agar petri plates.

$>$ The plates were then incubated for 24 hours at $30^{\circ} \mathrm{C}$. 


\section{6: Specimen Processing}

The fish specimens were cut into $1-2 \mathrm{~cm}$ pieces and put into three different fermentation experimental media and a control medium in four different flasks (flask 1-4). Flask 1 contained HS media along with Dough culture, flask 2 contained HS media and Yogurt, flask 3 contained only HS media and flask 4 contained only distilled water (control medium). The flasks were then placed in incubator at $37^{\circ} \mathrm{C}$. The samples (soup specimens) were taken on weekly bases from the incubated flasks.

\section{7: Extraction of Type 1 Collagen}

\subsection{1: Trichloroacetic acid (TCA) Precipitation}

$10 \mathrm{ml}$ of soup specimen was taken in four different $50 \mathrm{ml}$ tubes from the flasks on weekly bases e.g. day 0 , day 7, day 14, day 21 and day 28. One each week, the $\mathrm{pH}$ of the flasks was observed and noted carefully. The specimen was centrifuged on $4{ }^{\circ} \mathrm{C}$ at $4500 \mathrm{rpm}$ for 10 minutes on ultracentrifuge. After ultra-centrifugation, $3 \mathrm{ml}$ of soup was taken and transferred in to $15 \mathrm{ml}$ tubes. Then these tubes were centrifuged at $2000 \mathrm{rpm}$ for 5 minutes on ordinary centrifuge. Then from each tube, $900 \mu 1$ of soup was transferred to 12 different $1.5 \mathrm{ml}$ Eppendorf tubes ( 3 tubes of each sample) and $100 \mu \mathrm{l}$ of TCA was added to each tube and mixed constantly. The Eppendorf tubes were then kept on $-20^{\circ} \mathrm{C}$ for 20 minutes.

After 20 minutes of freezing, the samples were centrifuged at 12,000 rpm for 10 minutes on Microspin. After centrifugation, the soup was discarded and $1 \mathrm{ml}$ of $80 \%$ cold Acetone was added to each tube and centrifuged again at 10,000 rpm for 3 minutes on Microspin. The Acetone was discarded after centrifugation and $1 \mathrm{ml}$ of fresh Acetone was added and centrifuged again. This process was repeated 2-3 times. After centrifugation, the Eppendorf tubes were put up side down for drying. After drying, $100 \mu \mathrm{l}$ of distilled water was added and preserved at $-20{ }^{\circ} \mathrm{C}$ for further processing. 
2.7.2: Gel Electrophoresis

6\% Resolving Gel SDS-PAGE

Requirements

- $\quad 30 \%$ Acrylamide mix

- $\quad$ 1.5 M Tris ( $\mathrm{pH} 8.8)$

- $\quad 10 \%$ SDS

- $\quad 10 \%$ Ammonium Persulfate

- TEMED

- Distilled water

\section{5\% Stacking Gel SDS-PAGE}

\section{Requirements}

- $\quad 30 \%$ Acrylamide mix

- $\quad$ 1.0 M Tris (pH 6.8)

- $10 \% \operatorname{SDS}$

- $\quad 10 \%$ Ammonium Persulfate

- TEMED

- $\quad$ Distilled Water
Components Gel Volume (10ml)

$2 \mathrm{ml}$

$2.5 \mathrm{ml}$

$0.1 \mathrm{ml}$

$0.1 \mathrm{ml}$

$0.008 \mathrm{ml}$

$5.3 \mathrm{ml}$
Component Gel Volume (5ml)

$0.83 \mathrm{ml}$

$0.63 \mathrm{ml}$

$0.05 \mathrm{ml}$

$0.05 \mathrm{ml}$

$0.005 \mathrm{ml}$

$3.4 \mathrm{ml}$ 


\section{Methodology}

The collagen type 1 was hydrolyzed by SDS-PAGE (sodium-dodecyl sulfate polyacrylamide gel electrophoresis) with $6 \%$ resolving gel. The gel was then kept for 45 minutes. The gel was pipetted with isopropanol to avoid oxygen inhibition of the polymerization reaction and to make the surface uniform. Then the 5\% stacking gel was loaded over the resolving gel and kept for 30 minutes. Prior to electrophoresis, $100 \mu \mathrm{l}$ of SDS buffer (denaturing buffer) was loaded in to it and heat shock of $95^{\circ} \mathrm{C}$ for 5 minutes was given to the samples to convert the complex protein structure to linear form. Then Gyangnam protein marker and $10 \mu \mathrm{l}$ of each sample was loaded on gel wells. The gel tray was placed in Glycine buffer and run for 25 minutes of at 100 volts. After 25 minutes, the electric voltage was increased to 200 volts to achieve the perfect bands on resolving gel. Once the electrophoresis was completed, the gel was dyed with Coomassie Blue Brilliant G-250 Dye and incubated in shaking incubator for 24 hours at $30^{\circ} \mathrm{C}$. then the samples were washed with acetic acid and methanol and photographed subsequently. Collagen type 1 and its hydrolyzed form were observed clearly.

\section{8: Cell Culture and Reagents}

HaCaT cells, spontaneously immortalized human epidermal keratinocytes, were purchased from CLS Cell Line Service and cultured in Dulbecco's modified Eagle's medium supplemented with $10 \%$ fetal bovine serum, $100 \mathrm{IU} / \mathrm{mL}$ penicillin, and $100 \mathrm{mg} / \mathrm{mL}$ streptomycin in a humidified $5 \%$ atmosphere at $37^{\circ} \mathrm{C}$. Sub-confluent cells were harvested with trypsin-EDTA and used for further experiments.

\subsection{1: Cell cytotoxicity Assay}

HaCaT cells $\left(1 \times 10^{4}\right.$ cells/well $)$ were cultured in 96-well flat-bottom culture plates and treated with appropriate doses of FFCP for 24 and 48 hours. Cell viability was determined using the colorimetric WST-1 conversion assay using EZ-Cytox assay kit and as per manufacturer's instructions and the percent cell viability was calculated. Experiments were performed in triplicates. 


\section{9: Biochemical tests for identification of Bacterial species used in fermentation}

Bacterial culture is commonly identified by different biochemical tests. These biochemical tests are applied for the identification of enzymes, proteins or peptides based on biochemical activities of these enzymes and peptides. These biochemical tests give an accurate result is short time. Some biochemical tests are used in this study to identify the bacteria. Some biochemical tests used here are; oxidase test, catalase test and urease test.

\subsection{1: Catalase test}

This test is commonly used for the identification of an enzyme catalase secreted by many bacterial species during the growth. Some of the bacterial species produce this enzyme to catalase hydrogen per oxide to oxygen and water molecule. Bacillus species produce catalase enzyme which convert $\mathrm{H}_{2} \mathrm{O}_{2}$ to oxygen and water molecule. When bubbles are produced in the solution, then the bacterial sample is indicated as catalase positive.

\section{Principle}

The enzyme converts hydrogen per oxide to oxygen and water molecule. Bacterial culture to be tested is brought in contact with the hydrogen per oxide in a sterile test tube to check out the catalase activity of the culture. Whenever a bacterial culture is catalase positive it produces oxygen in the form of bubbles in the test tube. Which indicates that the culture is catalase positive. But one thing should be noticed that the culture to be tested should be fresh and should be 24 hours old.

\section{Reagents}

Hydrogen per oxide (3\%), is used for the identification of catalase enzyme. 


\section{Procedure}

About 2-3 drops of $\mathrm{H} 2 \mathrm{O} 2$ is poured into an autoclaved test tube. 2-4 similar culture colonies are picked though an autoclaved cotton stick and are mixed with the solution present in the test tube. The catalase positive bacterial culture releases an enzyme, catalase enzyme, which converts hydrogen per oxide to water molecule and oxygen in the form of bubbles. The bubbles are examined by naked eyes with in few seconds.

\subsection{2: Urease test}

Some bacterial species hydrolyze urea and convert it in to constituents with in short of the time, like bacillus species. This test is used routinely as a diagnostic laboratory mostly.

\section{Principle}

Some bacterial culture produces an enzyme which may able to hydrolyze urea into carbon dioxide and ammonia in the presence of water molecules. The combination of these sub constituents, water molecules, ammonia and carbon dioxide results into ammonium carbonate. The presence of ammonium carbonate turns the culture medium into alkaline and turns the color of phenol red (an indicator) from yellow to bright pink color.

\section{Procedure}

The medium is prepared and autoclaved at $121^{\circ} \mathrm{C}$ for 15 minutes. After, the medium is filled into the autoclaved test tubes. The broth medium in the test tube is inoculated with the help of sterilized wire loop. Pure culture is inoculated into the test tubes. The slant of each test tube is inoculated with the sample culture. After, the capes of the test tubes were kept at loose condition and the samples were incubated at $35^{\circ} \mathrm{C}$ for about $20-24$ hours. When the color of the medium turns to pink color, means alkaline condition.

\subsection{3: TSI (triple sugar iron):}

It is a microbiological test to test capability of microorganism's ability that can ferment sugar and can produce $\mathrm{H}_{2} \mathrm{~S}$ (hydrogen sulfide). It is a test that has triple sugar (glucose, sucrose, lactose) and iron. 


\section{Composition of TSI:}

Glucose, lactose and sucrose at concentration of 1:10:10(1-part glucose, 10-part lactose and 10-part sucrose).

Phenol red: for identification of acidification (it is red in alkaline condition and in acidic collection it is yellow.

It also has peptone as a source of nitrogen because in aerobic condition peptone when utilize it produce ammonia.

Iron: indicator of hydrogen sulfide.

\section{Procedure:}

1. bacterial colony was picked with a well sterilized wire lope.

2. Inoculate TSI agar in the test tube and made slants of TSI medium.

3. the cap was covered loosely and incubate it at $35^{\circ} \mathrm{C}$ for 24 hours.

\subsection{4: Indole test}

A test performed to observe the trait of an organism which can use and split tryptophan amino acid and form the indole compound.

An enzyme tryphtophanase hydrolyzed tryptophan to create three possible final products, indole is one of them. Kovac's or Ehrlich's reagent are comprised of 4(p)-dimethylamino benzaldehyde, which react with indole and produce red color compound which is a sign of indole production.

Two methods are in used;

- A test detect the very active creating indole organism called spot indole test.

- Passive creating indole organism are detected by conventional tube method which need require overnight incubation. 


\section{Methods}

Broth culture was inoculated to the tryptophan broth or the isolated colony of tested organism was emulsifying in tryptophan broth. Then it is incubated at $37^{\circ} \mathrm{C}$ for $24-28$ hours, and then $0.5 \mathrm{ml}$ of kovac's reagent was added to the broth culture.

\subsection{5: Citrate test:}

The citrate agar is used to check the ability of microorganisms that can use citrate as a sole of energy. Medium contain $\left(\mathrm{NH}_{4}\right)_{2} \mathrm{PO}_{4}$ (inorganic ammonium salt) as a source of nitrogen and citrate as carbon source. Bacteria which can grow in citrate agar media produce an enzyme called citrate permease which has the ability to convert citrate to pyruvate.

\section{Composition:}

Table 2-0-1: Composition of citrate agar medium

\begin{tabular}{|l|l|}
\hline Agar & $15.0 \mathrm{gm}$ \\
\hline Dipotassium phosphate & $1.0 \mathrm{gm}$ \\
\hline Ammonium dihydrogen phosphate & $1.0 \mathrm{gm}$ \\
\hline Magnesium sulfate & $0.2 \mathrm{gm}$ \\
\hline Bromothymol Blue & $0.08 \mathrm{gm}$ \\
\hline Sodium chloride & \\
\hline Sodium citrate & $5.0 \mathrm{gm}$ \\
\hline Deionized water & $2.0 \mathrm{gm}$ \\
\hline
\end{tabular}




\section{Procedure:}

1. Well isolated Bacterial colony was picked and streak the citrate slant back and forth.

2. Placed that citrate slants in incubator at $35^{\circ} \mathrm{C}$ for 3 days

3. Observed a blue color which was changed from green due to alkalanization that means test is positive.

\subsection{6: Methyl red test:}

In methyl red test detects that microorganisms which can perform mixed acid fermentation after supply of glucose.

\section{Media and Reagents:}

\section{Methyl red solution, $0.02 \%$}

$0.1 \mathrm{gm}$ of methyl red which is already dissolved in three hundred (300 ml) of ethyl alcohol, 95 percent.

$500 \mathrm{ml}$ distilled water.

Stored at $4^{\circ} \mathrm{C}$ in a bottle.

\section{Procedure:}

1. before inoculation media was allowed to adjust at room temperature.

2. 24 hour cultured bacteria was taken and inoculate in medium.

3. Kept in incubator for 24 hours at $36^{\circ} \mathrm{C}$.

4. Added 3 drops of methyl red indicator to already incubated media.

5. Color changed to red was observed which mean test is positive 


\section{RESULTS}

\section{Culturing:}

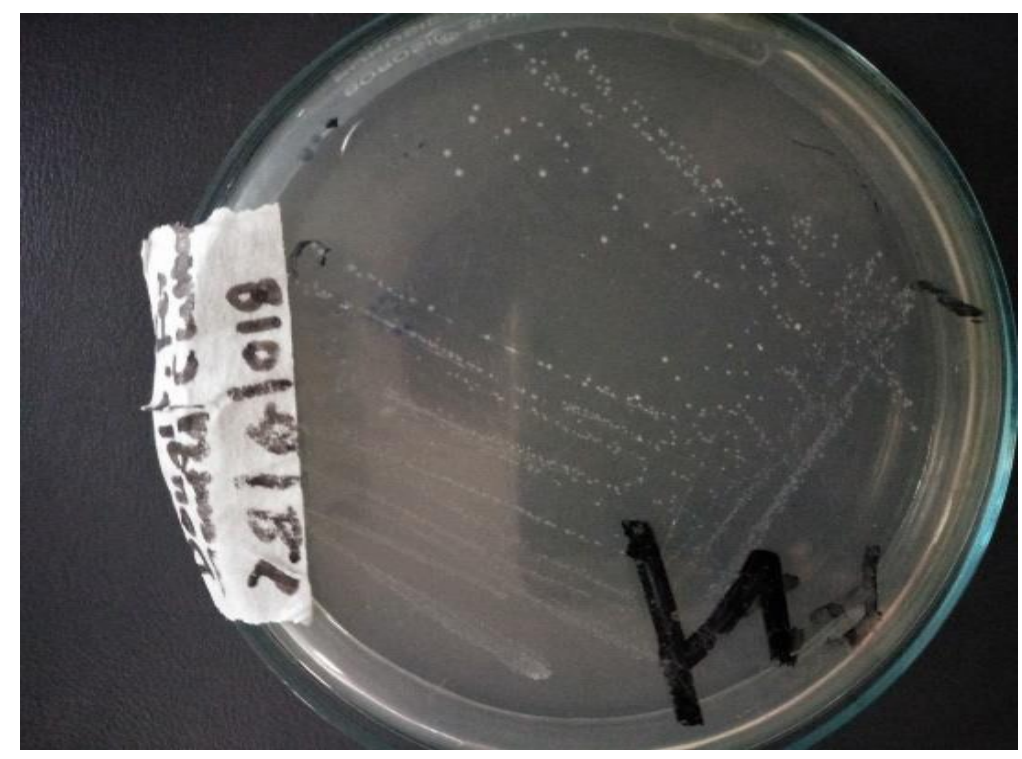

Figure 3-1: Culturing of dough by serial dilution using HS Media

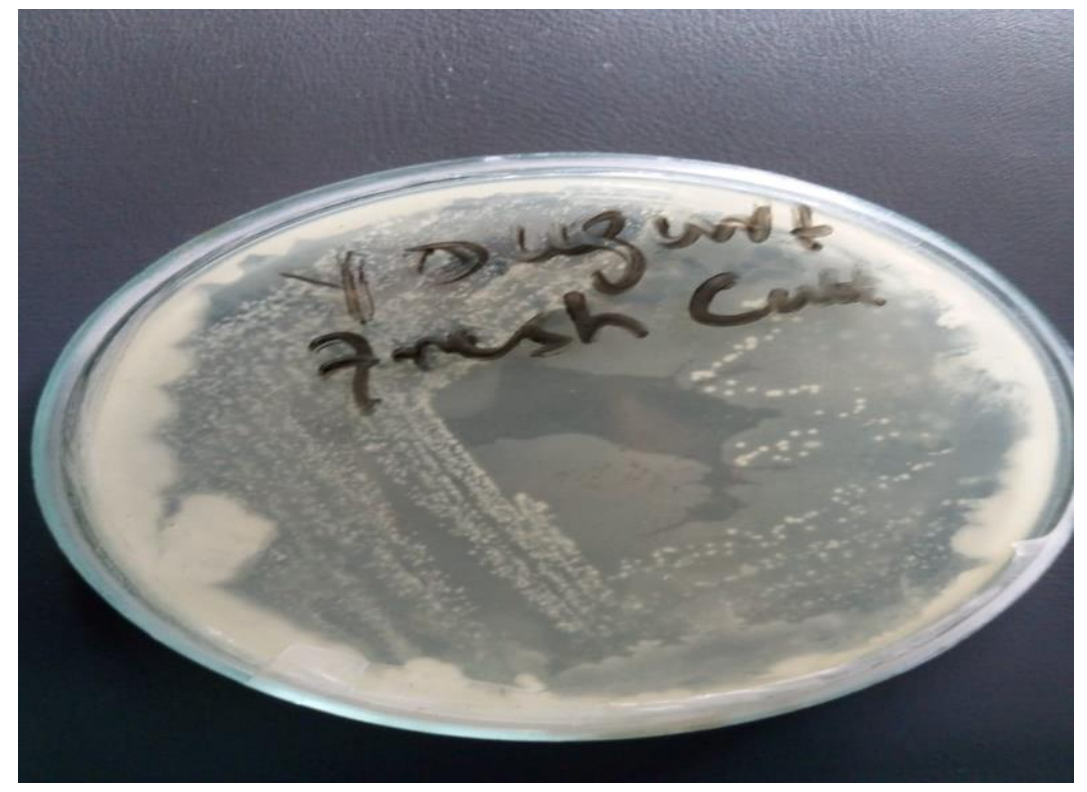

Figure 3-2: Culturing of yogurt by serial dilution using HS media 


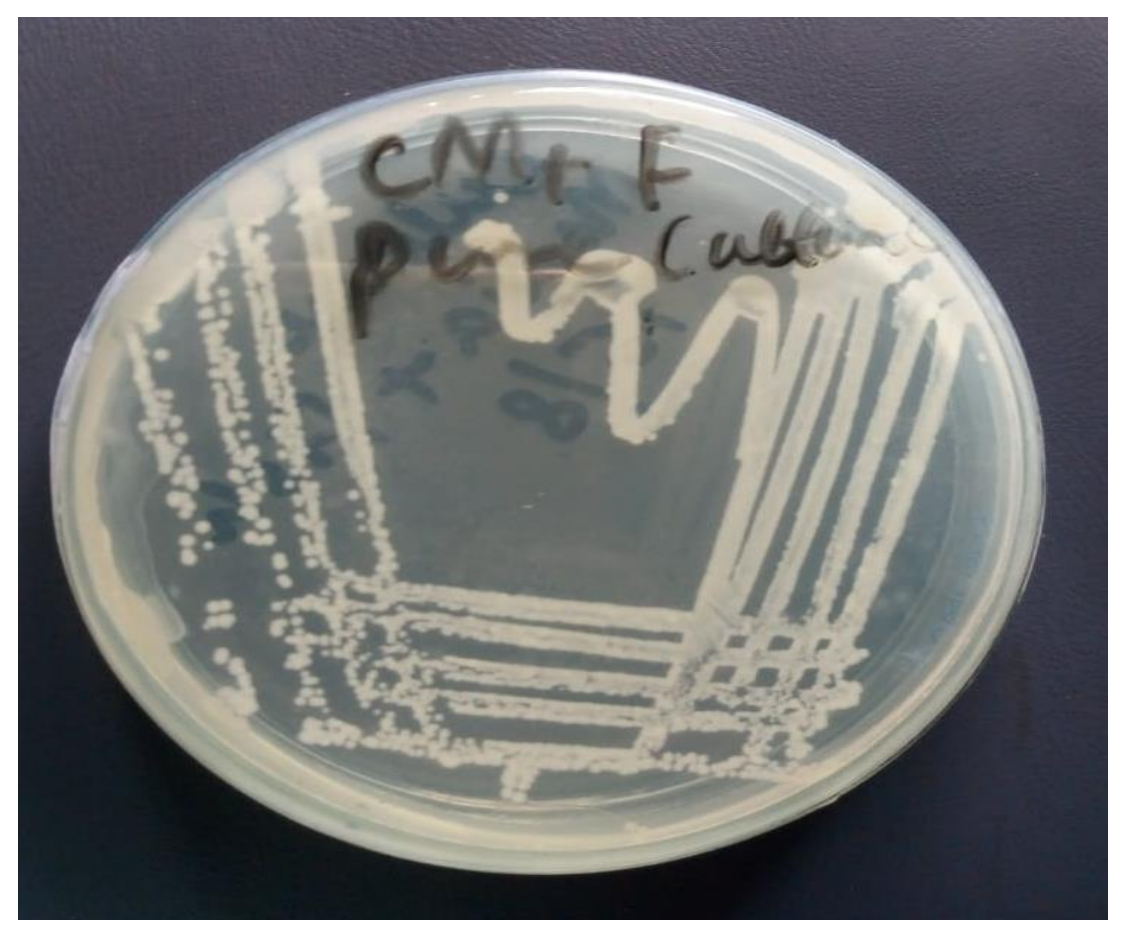

Figure 3-3: HS culture media + fish culturing

Colonies from these cultured petri plates were taken and added to fermented flasks which has already fish pieces and HS media.

\section{Fermentation:}

Fish pieces along with HS culture media and dough, yogurt culture taken in $150 \mathrm{ml}$ flasks and kept in incubator at $30^{\circ} \mathrm{c}$. 


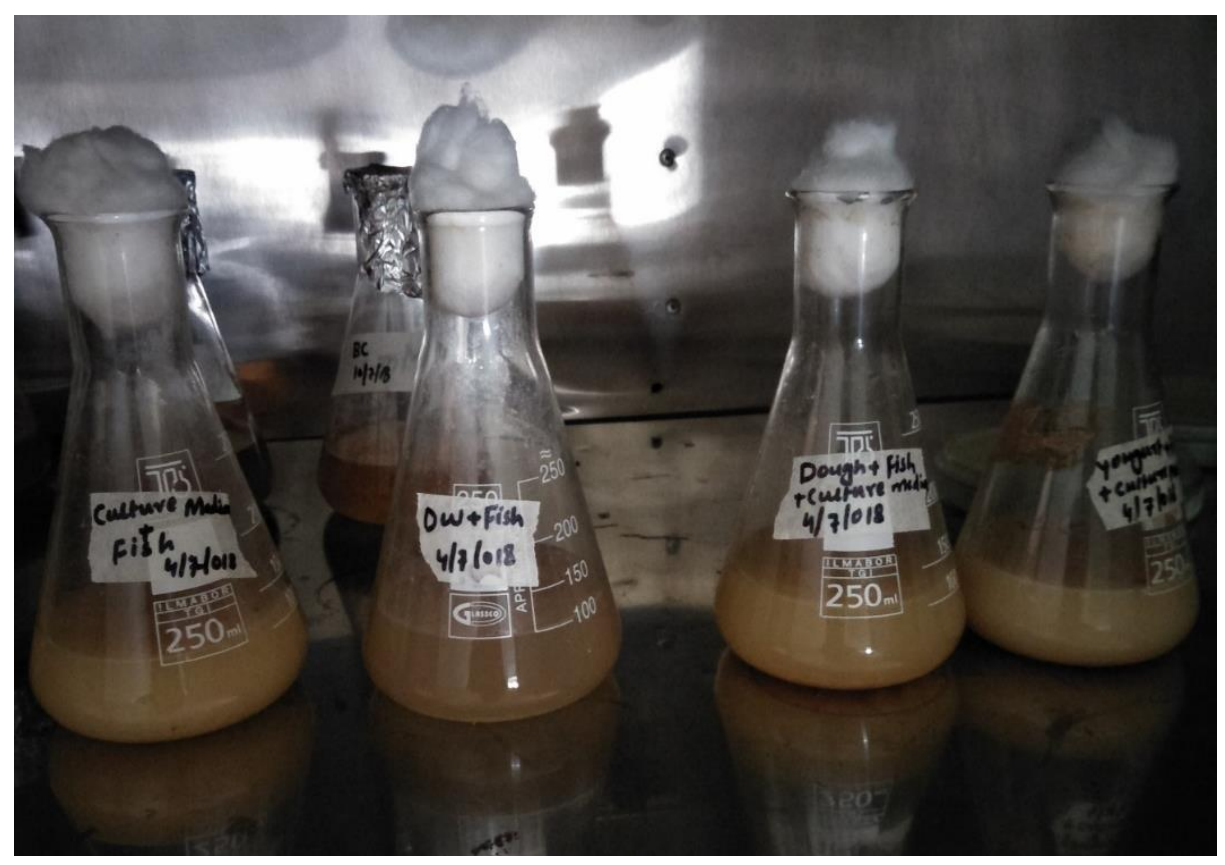

Figure 3-4: Fermented flasks

\section{1: Collagen Extraction Optimization:}

For the extraction of fish collagen, preliminary studies were carried out for the identification of suitable extraction parameters. The samples were set at $37^{\circ} \mathrm{C}$ and the changing $\mathrm{pH}$ was carefully observed and noted down for four weeks. Table 3.

Table 3-1: Optimization of pH during four weeks' duration

\begin{tabular}{|l|l|l|l|l|l|}
\hline Samples & Day 0 & $\begin{array}{l}\text { Week 1 } \\
\mathrm{pH}\end{array}$ & $\begin{array}{l}\text { Week 2 } \\
\mathrm{pH}\end{array}$ & $\begin{array}{l}\text { Week 3 } \\
\mathrm{pH}\end{array}$ & $\begin{array}{l}\text { Week 4 } \\
\mathrm{pH}\end{array}$ \\
\hline Distilled Water + Fish & 8 & 8 & 8 & 9 & 9 \\
\hline Culture Media + Fish & 6 & 6 & 5 & 6 & 6 \\
\hline Yogurt + Fish & 5 & 5 & 4 & 5 & 5 \\
\hline Dough + Fish & 4 & 4 & 5 & 5 & 4 \\
\hline
\end{tabular}




\section{Centrifugation:}

Firstly, samples from all four flasks were centrifuge at 4500rpm for 10 minutes at $4^{\circ} \mathrm{c}$ and then take soup and again centrifuge in Microspin at 10000rpm for 3 minutes.

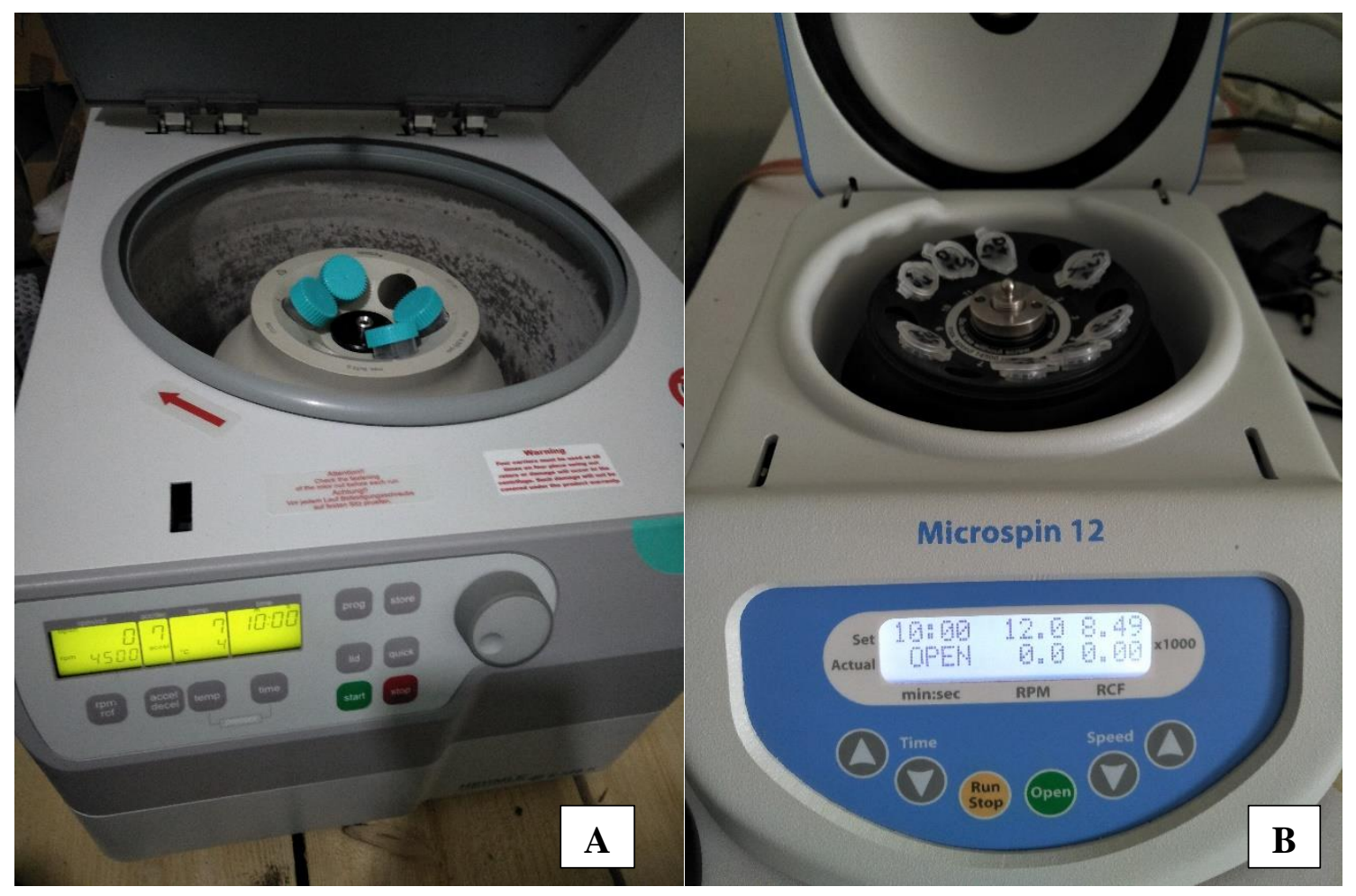

Figure 3-5: A. Ultra-Centrifuge, B. Micro spin Centrifuge

\section{2: Gel Electrophoresis}

The extracted collagen protein profile was observed with commercially available sodium-dodecyl sulfate polyacrylamide gel electrophoresis (SDS-PAGE). The SDS-PAGE revealed that the collagen protein of fish had doublet pattern for $\alpha 1$ and $\alpha 2$ chains at corresponding to $145 \mathrm{kDa}$ and $132 \mathrm{kDa}$ respectively. The density for $\alpha 1$ twice as compared to $\alpha 2$.

The fish collagen consists mostly of $\alpha$-chain as well as little amount of inter and intra molecular cross-linked components of $\alpha$-chains; $b$ (dimmer) and c (trimer). This type of dimmer and trimer were seen in collagen of bigeye snapper (Kittiphattanabawon et al., 2005), back drum sea bream, sheephead sea bream (Ogawa et al., 2003), and ocellate puffer fish (Nagai et al.,2002). That's why 
it's proved that lycine derived cross link was present in the soluble collagen fraction of scales (Kimura et al.,1991).

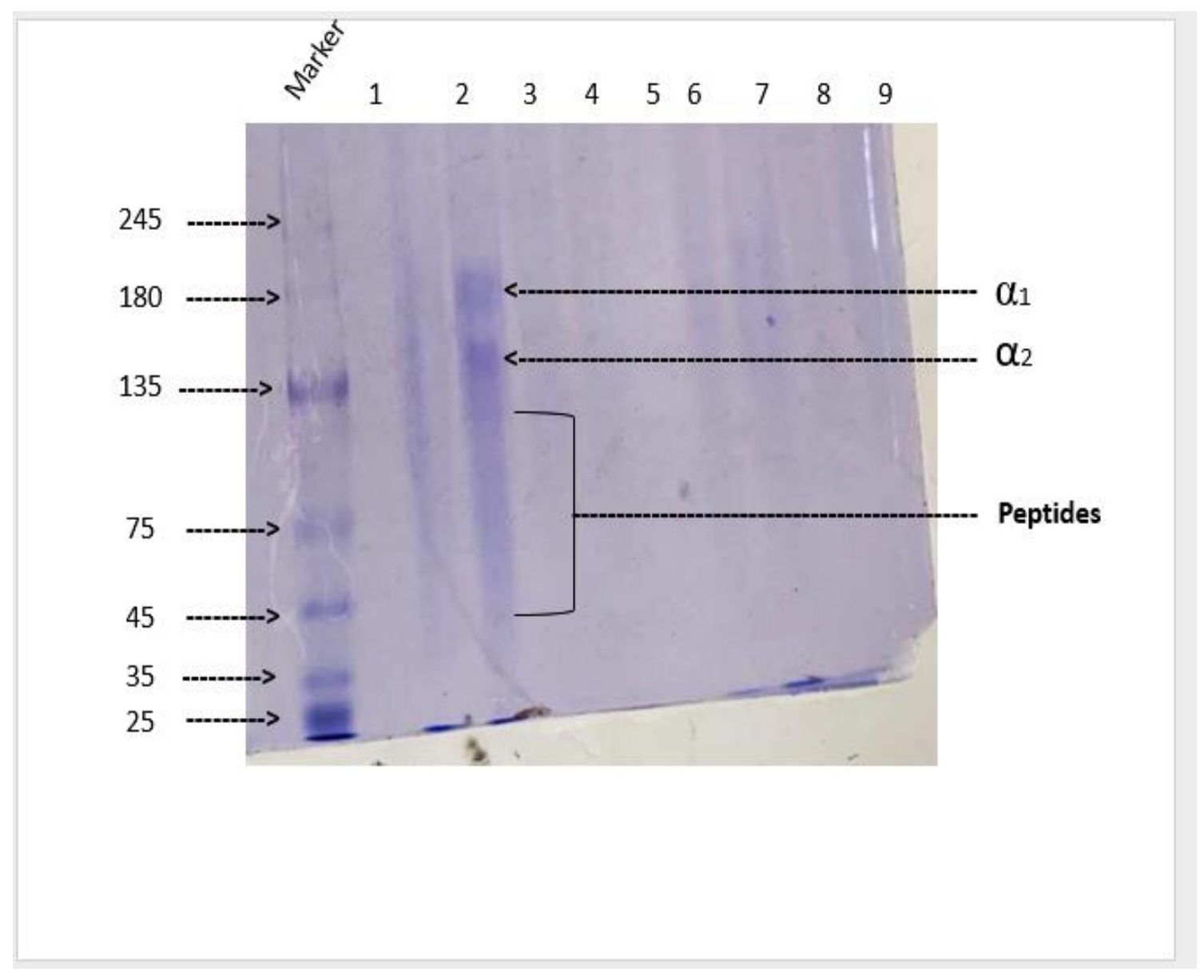

Figure 3-6: SDS-PAGE analysis of (1) distilled water +fish (2) yogurt +fish week1 (3) yogurt +fish week2 (4) yogurt +fish week3 (5) dough +fish week1 (6) dough +fish week3 (7) dough +fish week3(8) HS culture media +fish. 


\subsection{Biochemical tests:}

\section{Catalase test:}

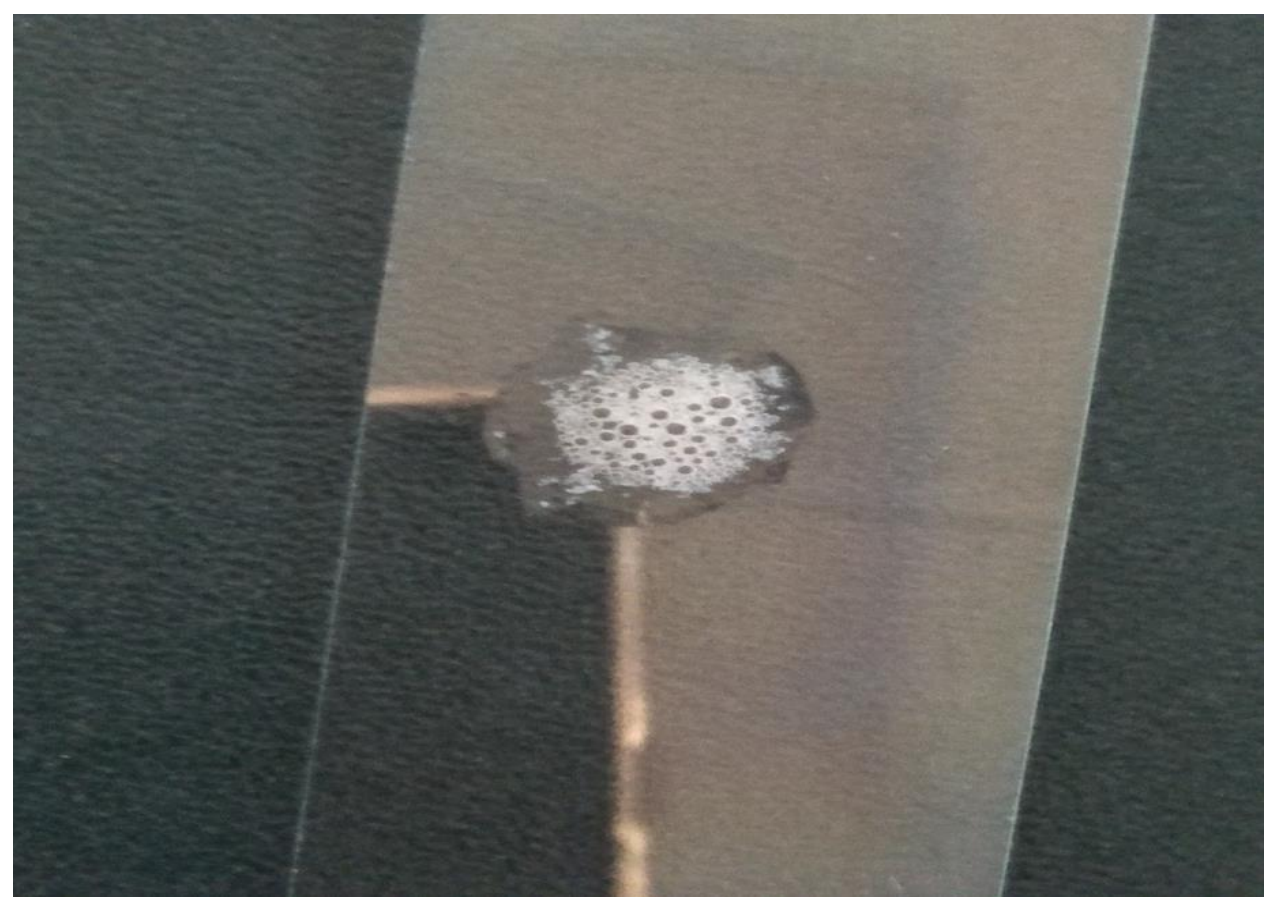

Figure 3-7: Catalase positive test

In catalase test four slides were taken and bacterial smear was formed. One drop of $\mathrm{H}_{2} \mathrm{O}_{2}$ was added. Bubbles were noticed for the results. 


\section{Urease test}

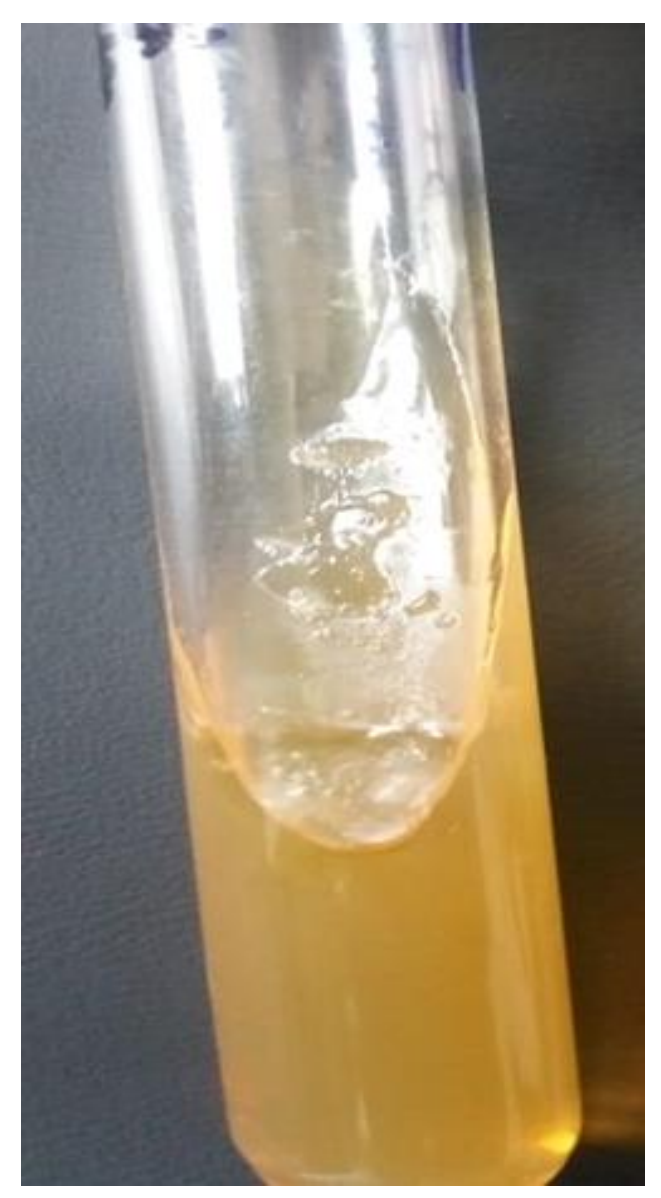

Figure 3-8: Urease negative test

In urease test urease agar was used for this test. Slants were prepared and yougurt cultures were streaked on them. These slants were incubated for 24 hours. No Color change was observed after 24 hours. 


\section{Tsi (triple sugar iron agar) test:}

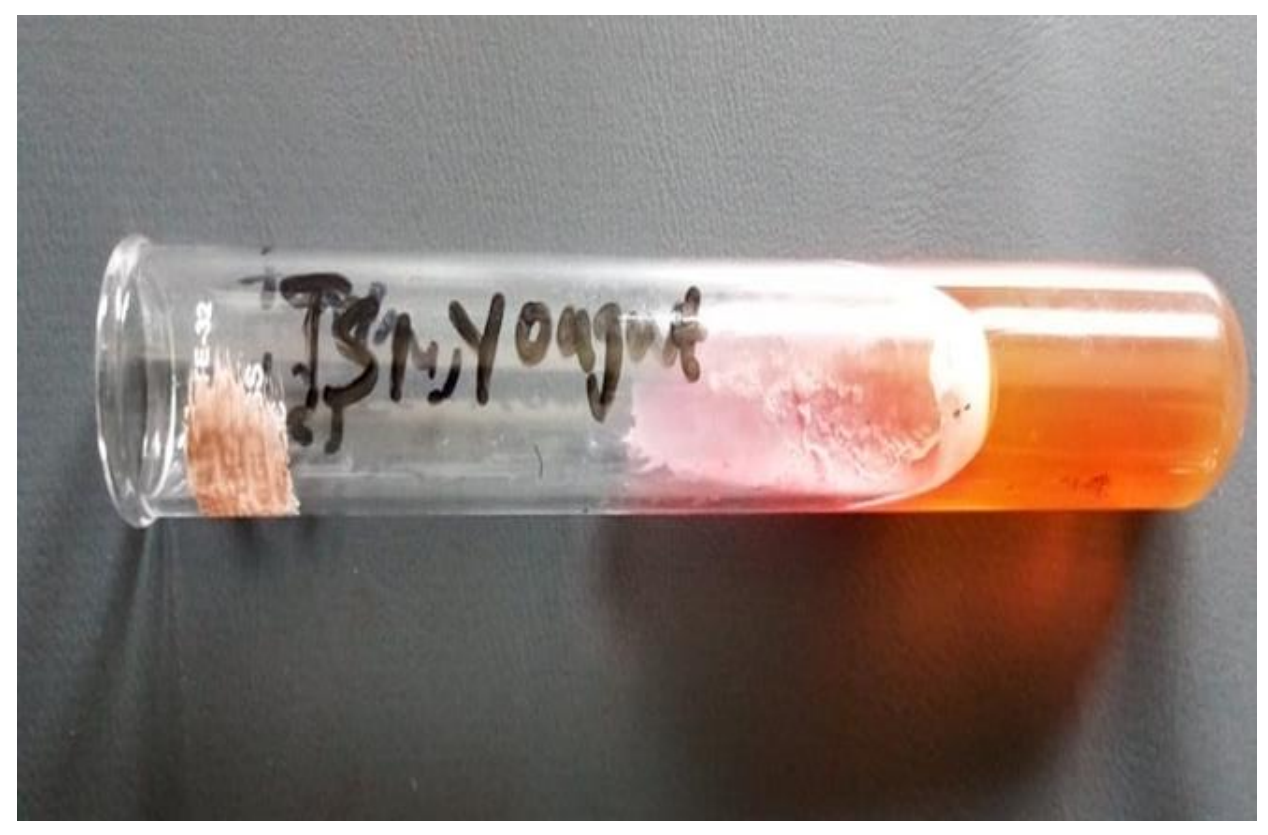

Figure 3-9: Tsi (triple sugar iron agar) positive

- In TSI test TSI slants were formed by using TSI agar and cultures were streaked on them. After 24 hours' incubation it was observed for color change. 


\section{Citrate test:}

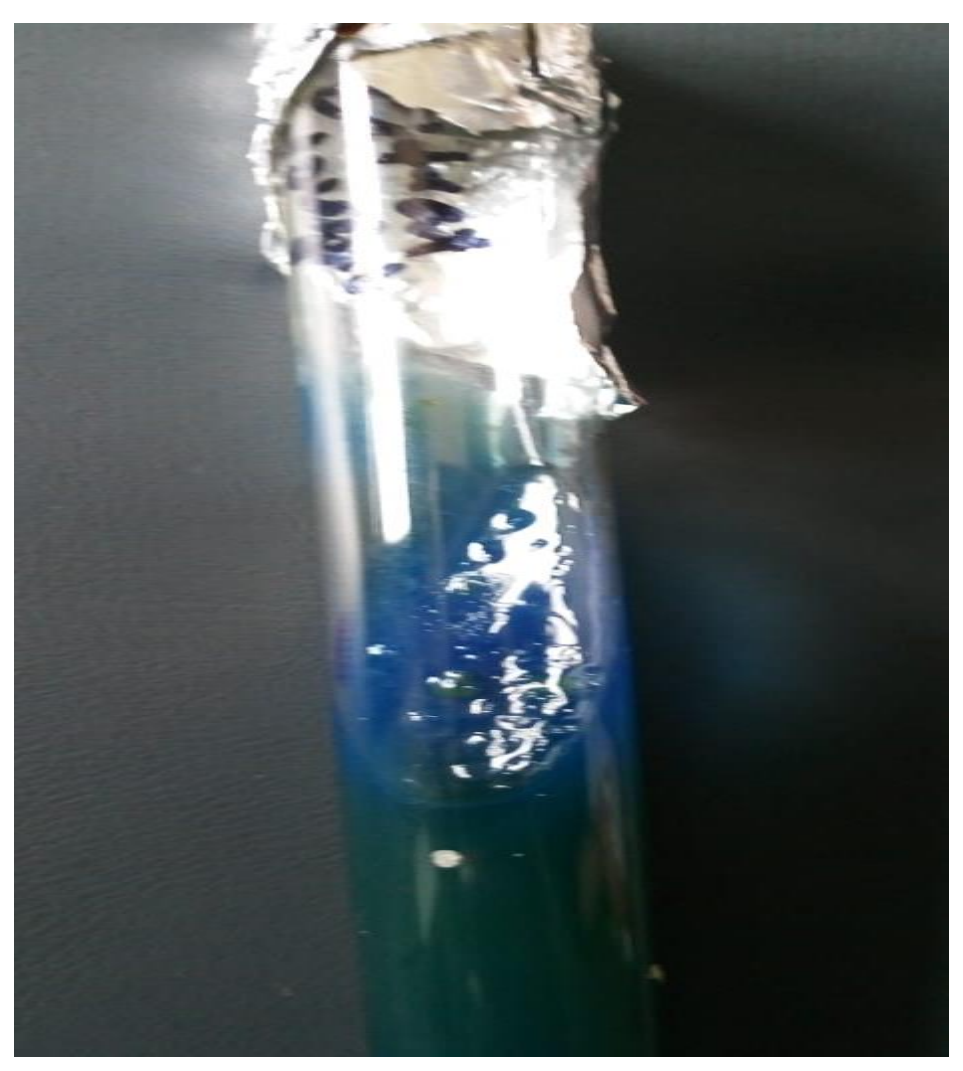

Figure 3-10: Citrate positive test

- In citrate test Simmons citrate agar was used to test either organism has ability to utilize citrate as the sole source of energy. This medium contains ammonium salts as nitrogen and citrate as carbon source. Slants were formed and cultures were streaked on them. Color change was observed after incubation for the results. 


\section{Indole test:}

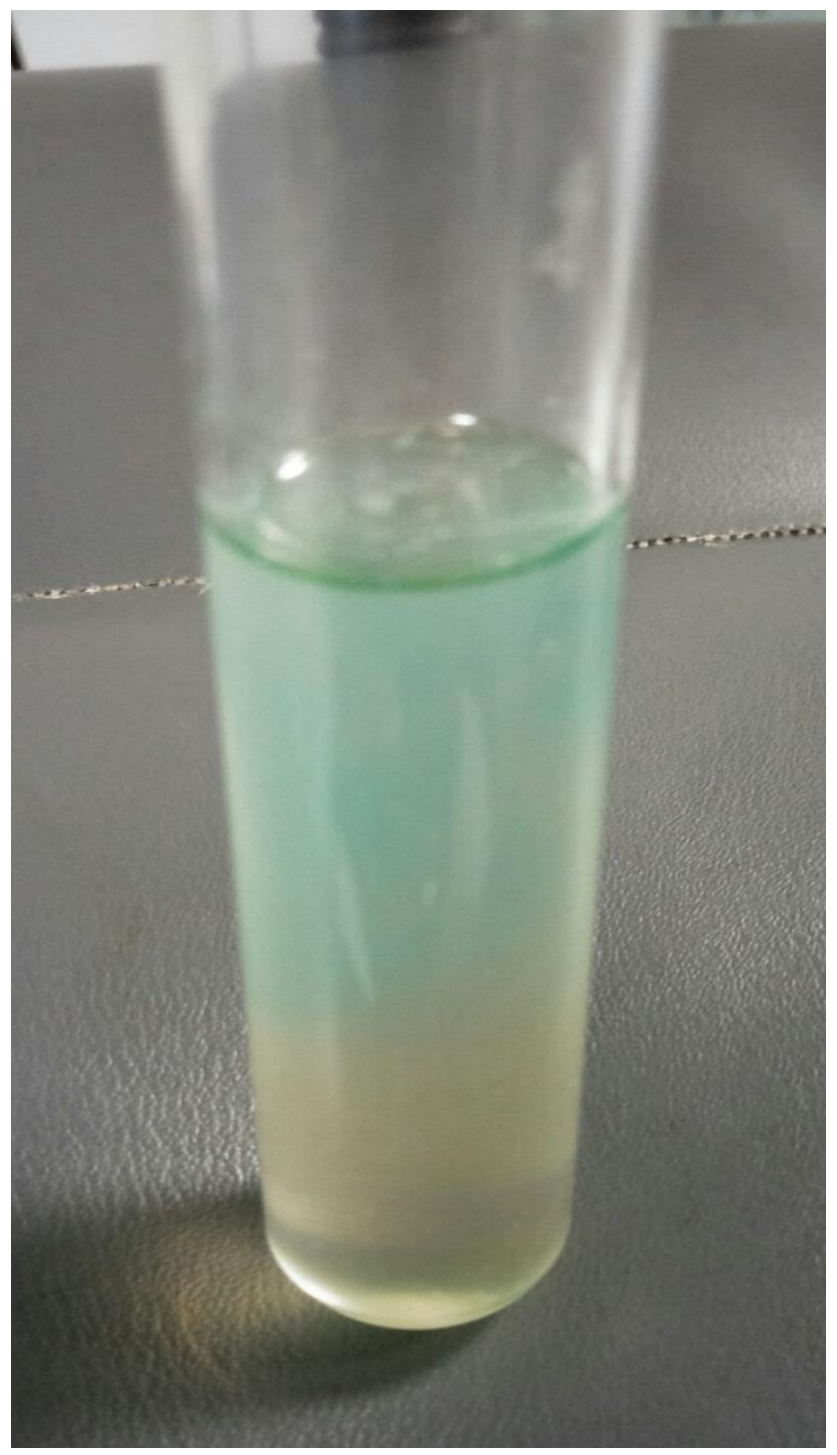

Figure 3-11: Indole negative test

In indole test peptone broth was prepared and autoclaved. Then cultures were inoculated into tube with sterile loop. These cultures were incubated for 24 hours. After incubation kovac's reagent (isoamyl alcohol, para Dimethylaminobenzaldehayde and concentrated $\mathrm{HCl}$ ) was added in the culture broth. No red and violet rings were formed on the surface 
which indicate positive so solution turns yellow. Variable, showing an orange color which is negative.

\section{Methyl red test:}

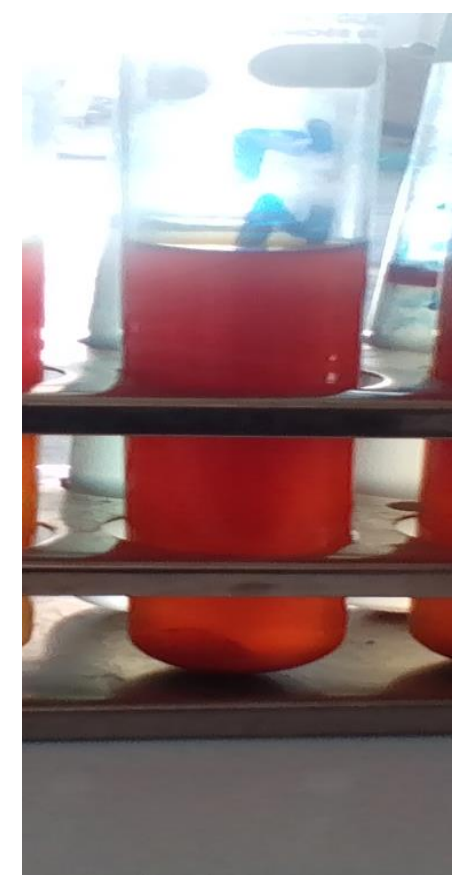

Figure 3-12: Methyl red positive test

- In methyl red test nutrient broth media was formed and poured in test tubes. Culture were added in these tubes and incubated for 24 hours. After incubation 5 drops of methyl red were added in the inoculums. Color change was observed for the results. 


\section{Cell Culturing:}

Cell proliferation of $\mathrm{HaCaT}$ cell after treatment with fermented fish collagen peptides

Table 3-2: Treatment after 24hr

\begin{tabular}{|l|l|l|}
\hline \multirow{2}{*}{ 4hhr } & control & Treated FFCP \\
\hline & 0.6 & 1.2 \\
\cline { 2 - 4 } & 0.65 & 0.9 \\
\cline { 2 - 4 } & 0.61 & 0.81 \\
\hline STD & & 0.204205779 \\
\hline SUM & 0.264575131 & 0.778551445 \\
\hline$\%$ & 0.531143783 & 146.5801672 \\
\hline
\end{tabular}

Table 3-3: Treatment after 48hr

\begin{tabular}{|l|l|l|}
\hline 48hr & control & Treated FFCP \\
\hline \multirow{2}{*}{} & 1.2 & 2.1 \\
\cline { 2 - 4 } & 1.28 & 1.8 \\
\cline { 2 - 4 } & 1.23 & 2.3 \\
\hline STD & & 0.251661148 \\
\hline SUM & 0.606217783 & 1.612915287 \\
\hline$\%$ & 1.079054446 & 149.4748753 \\
\hline
\end{tabular}




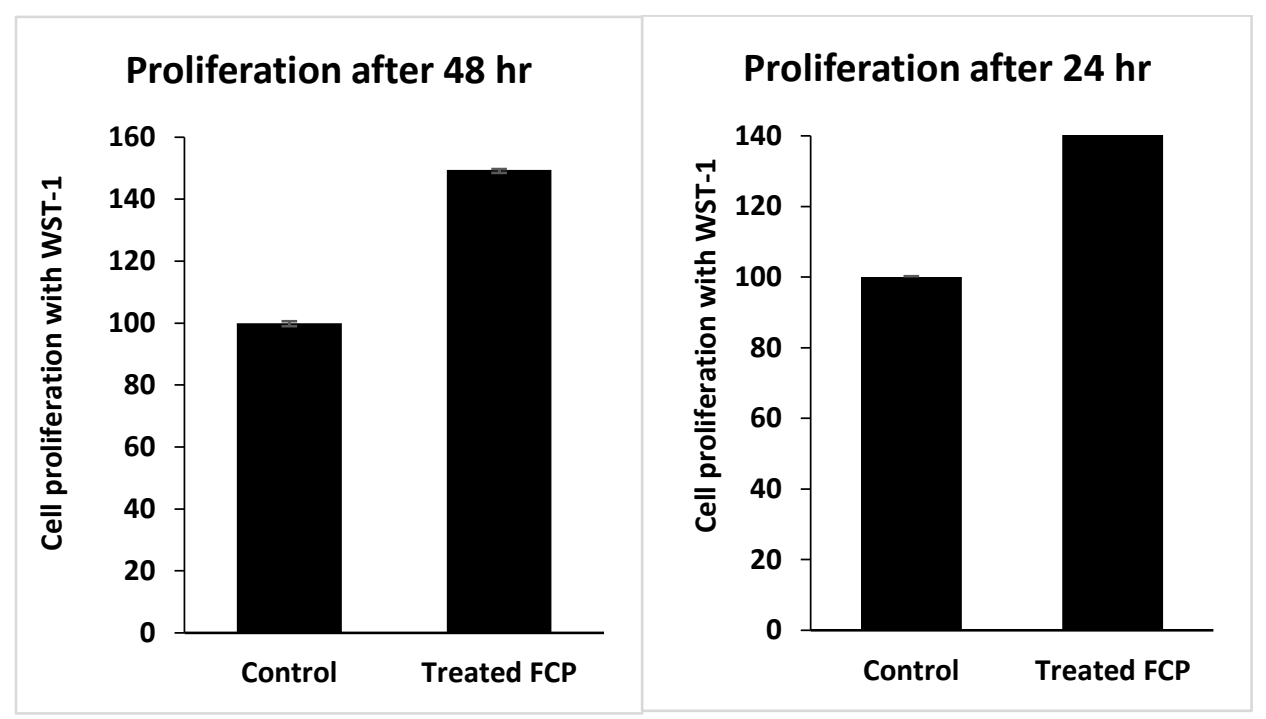

Figure 3-13: The human skin keratinocytes were culture in a 96 well plate with $1 \times 104$ cell per well. The cells were treated with either HS culture media or with FFCP at the rate of $10 \mathrm{mg} / \mathrm{ml}$ for 24 and $48 \mathrm{hr}$ respectively 


\section{DISCUSSION}

Greek terms "kolla" means gum and "gen" means producing, have given the word collagen (Muralidharan et al., 2013). Connective tissue has collagen as the most vital protein, and all multicellular species possess it in several forms (Schmidt et al., 2016). Bone, skin, cartilage, smooth muscle and basal lamina has collagen, which is composed of a family of proteins. ECM and connective tissue possess collagen, the vital fibrous glycoprotein which hold the structural integrity of these tissues (Sandhu et al., 2012). In human recently 28 different proteins have recognized as collagen (Vrana et al., 2008). As collagen is a vital protein and has properties like physical and chemical properties, non-toxic and biocompatible, that's why used in cosmetic, pharmaceutical industry, biomedical materials and as food additives in food industry (Tylingo et al., 2016). Old age is main reason for the deficiency of collagen in our body which lead to the looseness of skin and other organs (Sibilla et al., 2015). To fulfill the deficiency of collagen in our body, currently collagen has been isolated from the marine source. It can be used for medicine purpose and 3D biomedical engineering too (Choi and Kim, 2015). Some religious issues, primarily in Islam and Judaism and the outbreak of bovine spongiform encephalopathy usually known as mad cow resulted the non-use of mammalian collagen. Fish collagen has been substituted of mammalian collagen as a source of collagen proteins (Mahboob, 2015). Skin, bones, fines and scales of fishes such jellyfishes, squids, sponges, octopuses, fish offal and cuttlefishes are used as source of collagen proteins (Tamilmozhi et al., 2013). Successful isolation of collagen has several applications in cosmetics, food science and biomedicine (Berillis, 2015).

The current study was designed to extract collagen from fish through fish waste fermentation under various conditions. The fish waste treated with yogurt and dough culture was analysed by SDSPAGE (sodium-dodecyl sulfate polyacrylamide gel electrophoresis) using $6 \%$ resolving and 5\% stacking gel. The collagen optimization and its cytotoxic studies were performed using HaCaT cell-lines.

It is well known that different strains of enterobacteriaceae and lactic acid Bacteria mostly spoil different food types. $0,12-15$. although mostly studies on just one or two type of foods. in this study we also discuss lactic acid bacteria are most dominant bacteria which can spoil food waste at temperature between $28^{\circ} \mathrm{C}$ and $35^{\circ} \mathrm{C}$. $\mathrm{LAB}$ is well known bacteria which can play an essential role in food preservation and fermentation by lowering PH and reproduce bacteriocins which can stop the production of different pathogenic microorganisms.so in our study that's why we used 
dough and yogurt bacteria which is safe to use and also anti pathogenic bacteria. So the presence of LAB indicates change in PH So with increase in lacto bacillus PH increase (Newton and Gill, 1978). In our study we observe PH on weekly basis so in first week have much change in PH but with time the $\mathrm{PH}$ become stable. This might recognize high oil content and low PH cause by fish waste in relative anaerobic condition.

According to our result lacto bacillus isolation from yogurt and dough was more as compared to cheese. In yogurt and dough have at least 10 type of lactic acid bacteria yogurt and cheese has much importance bio medically as it is safe to use and its non-pathogenic. In cheese have dominant species of lactobacillus that is get from raw dairy products because these bacteria can grow in harsh environment (Torres-Llanez et al., 2006). But according to our results about 10 different LAB strains from dough and yogurt was isolated. Decrease in different things like loss of probiotic growth in yogurt like presence of hydrogen, low PH, increase in acidity etc.

So all of the above studies are same to our study. Results of our study showed that Bacillus subtilis was one of the common specie isolated from yogurt and dough culture fermentation, although many studies are not same to our study.

The SDS-PAGE revealed that the collagen protein of fish had doublet pattern for $\alpha 1$ and $\alpha 2$ chains at corresponding to $145 \mathrm{kDa}$ and $132 \mathrm{kDa}$ respectively. The density for $\alpha 1$ twice as compared to $\alpha 2$. Our result agrees that The fish collagen consists mostly of $\alpha$-chain as well as little amount of inter and intra molecular cross-linked components of $\alpha$-chains; $b$ (dimmer) and c (trimer). This type of dimmer and trimer were seen in collagen of big eye snapper (Kittiphattanabawon et al., 2005), back drum sea bream, sheep head sea bream (Pati et al., 2010), and ocellate puffer fish (Nagai et al., 2002). That's why it's proved that lysine derived cross link was present in the soluble collagen fraction of scales (Pati et al., 2010).

In general, temperature, $\mathrm{pH}$, extraction time and the acid influence affect the yield of collagen. Raise in temperature and increase in time improved the yield of collagen, until it reached to optimum level of $37^{\circ}$ (Gudmundsson and Hafsteinsson, 1997). We optimized the production of fish waste fermentation using different temperature form $30^{\circ} \mathrm{C}$ to $37^{\circ} \mathrm{C}$. On the other hand, declining of yield production starts after optimum conditions as the collagen is thermos-stable and denatures easily at room temperatures due to its chemical structure (Pang, 2016). The conformation of collagen may alter with high temperature for longer time that could reduce the solubility of collagen. Thus, collagen yield declines with rising temperature and lengthening the time. The 
amino acids composition of the fish collagen varies between species. The collagen with a lesser hydroxyproline amount exhibits a lesser thermal stability as compared to its higher amount in collagen (Karim and Bhat, 2009a).

Moreover, the $\mathrm{pH}$ concentration also contributes the collagen's extractability. $\mathrm{pH}$ can control the protein's charge density that modify the structure and electrostatic interaction of the protein (Shen et al., 2008). In current study, the $\mathrm{pH}$ for each sample was observed on weekly bases (see table 3 ). Our fermented fish collagen and peptides mixture were test for cellular cytotoxicity and proliferative effect on $\mathrm{HaCaT}$ cells. Our result shows that fermented extracted collagen are nontoxic and induce the proliferation of HaCaT cells. Our results are supported by various studies that revealed the medical application of fish extracted collagen as underline.

Similarly, fish derived collagen peptides were also determined to promote HUVEC proliferation and inhibited IL-6, IL-8, and TNF- $\alpha$ production in lipopolysaccharide-stimulated HUVECs (Zhang et al., 2013). Recently, the marine collagen gained considerable attention because of their safety (Ólafsdóttir, 2003), and that become a key player in diverse biological properties, including antioxidant, anti-tumor (Ahmed et al., 2015), anti-hypertensive (Zhang et al., 2009), neuroprotective (Wong et al., 2015), anti-skin aging and epiphyseal growth-promoting (Saito et al., 2010), wound healing, and osteogenic and endothelial differentiation-promoting effects in rat bone marrow mesenchymal stem cells (Cavaliere et al., 2015). 


\section{REFERENCES}

Aewsiri, T., Benjakul, S., Visessanguan, W. \& Tanaka, M. (2008). Chemical compositions and functional properties of gelatin from pre-cooked tuna fin. International journal of food science \& technology, 43, 685-693.

Ahmed, M., Cheng, M., Zhao, Q., Goldgur, Y., Cheal, S. M., Guo, H.-F., Larson, S. M. \& Cheung, N.-K. V. (2015). Humanized Affinity-Matured Monoclonal Antibody 8H9 Has Potent Anti-Tumor Activity and Binds to FG Loop of B7-H3. Journal of Biological Chemistry, jbc. M115. 679852.

Badii, F. \& Howell, N. K. (2006). Fish gelatin: structure, gelling properties and interaction with egg albumen proteins. Food Hydrocolloids, 20, 630-640.

Beddows, C. G. (1998). Fermented fish and fish products. Microbiology of fermented foods. Springer.

Bella, J. (2016). Collagen structure: new tricks from a very old dog. Biochemical Journal, 473, 1001-1025.

Berillis, P. (2015). Marine collagen: Extraction and applications. Research Trends in Biochemistry, Molecular Biology and Microbiology; Madhukar, S., Ed, 1-13.

Birk, D. (2001). Type V collagen: heterotypic type I/V collagen interactions in the regulation of fibril assembly. Micron, 32, 223-237.

Burgeson, R. E. \& Morris, N. P. (1987). The collagen family of proteins. Connective Tissue Disease: Molecular Pathology of the Extracellular Matrix. Marcel Dekker, New York, NY.

Campbell-Platt, G. (1987). Fermented foods of the world. A dictionary and guide, Butterworths.

Campbell-Platt, G. (1994). Fermented foods - a world perspective. Food Research International, 27, 253-257.

Cavaliere, F., Donno, C. \& D'ambrosi, N. (2015). Purinergic signaling: a common pathway for neural and mesenchymal stem cell maintenance and differentiation. Frontiers in cellular neuroscience, 9, 211.

Choi, J. W. \& Kim, N. (2015). Clinical application of three-dimensional printing technology in craniofacial plastic surgery. Archives of plastic surgery, 42, 267. 
Chu, M. L., Mann, K., Deutzmann, R., Pribula-Conway, D., Hsu-Chen, C. C., Bernard, M. P. \& Timpl, R. (1987). Characterization of three constituent chains of collagen type VI by peptide sequences and cDNA clones. The FEBS Journal, 168, 309-317.

Council, R. (2002). Standard tables of food composition in Japan.

Da Rosa Zavareze, E., Storck, C. R., De Castro, L. a. S., Schirmer, M. A. \& Dias, A. R. G. (2010). Effect of heat-moisture treatment on rice starch of varying amylose content. Food Chemistry, 121, 358-365.

De Moraes, M. C. \& Cunha, R. L. (2013). Gelation property and water holding capacity of heattreated collagen at different temperature and $\mathrm{pH}$ values. Food Research International, 50, 213-223.

Duan, R., Zhang, J., Du, X., Yao, X. \& Konno, K. (2009). Properties of collagen from skin, scale and bone of carp (Cyprinus carpio). Food Chemistry, 112, 702-706.

Dun, R., Jackson, H. \& Smith, Y. (2008). Methods for processing and utilization of low cost fishes: a critical appraisal. J Food Sci Technol, 32, 1-12.

Dworkin, M. (2006). The Prokaryotes: Vol. 7: proteobacteria: delta and epsilon subclasses. Deeply rooting bacteria, Springer Science \& Business Media.

Ehrlich, H., Deutzmann, R., Brunner, E., Cappellini, E., Koon, H., Solazzo, C., Yang, Y., Ashford, D., Thomas-Oates, J. \& Lubeck, M. (2010). Mineralization of the metre-long biosilica structures of glass sponges is templated on hydroxylated collagen. Nature chemistry, 2, 1084.

Espe, M. \& Haaland, H. (1992). The protein value of fish silage prepared from capelin stored under different conditions before ensiling. Effect of storing the silage for one year. Fisk. Dir. Skr., Ser. Emaring, 5, 37-44.

Faid, M., Zouiten, A., Elmarrakchi, A. \& Achkari-Begdouri, A. (1997). Biotransformation of fish waste into a stable feed ingredient. Food Chemistry, 60, 13-18.

Fallas, J. A., Gauba, V. \& Hartgerink, J. D. (2009). Solution structure of an ABC collagen heterotrimer reveals a single-register helix stabilized by electrostatic interactions. Journal of Biological Chemistry, 284, 26851-26859.

Fernandes De Almeida, P., Guimarães Oliveira De Araújo, M. \& Curvelo Santana, J. C. (2012). Collagen extraction from chicken feet for jelly production. Acta Scientiarum. Technology, 34. 
Ferreira Da Silva, T. \& Barretto Penna, A. L. (2012). Colágeno: Características químicas e propriedades funcionais. Revista do Instituto Adolfo Lutz, (Impresso), 71, 530-539.

Gelse, K., Pöschl, E. \& Aigner, T. (2003). Collagens-structure, function, and biosynthesis. Advanced drug delivery reviews, 55, 1531-1546.

Gómez-Guillén, M., Giménez, B., López-Caballero, M. A. \& Montero, M. (2011). Functional and bioactive properties of collagen and gelatin from alternative sources: A review. Food Hydrocolloids, 25, 1813-1827.

Gómez-Guillén, M., Turnay, J., Fernández-Diaz, M., Ulmo, N., Lizarbe, M. \& Montero, P. (2002). Structural and physical properties of gelatin extracted from different marine species: a comparative study. Food Hydrocolloids, 16, 25-34.

Gordon, M. K. \& Hahn, R. A. (2010). Collagens. Cell and tissue research, 339, 247.

Gudmundsson, M. \& Hafsteinsson, H. (1997). Gelatin from cod skins as affected by chemical treatments. Journal of Food Science, 62, 37-39.

Inoue, S., Suzuki-Utsunomiya, K., Komori, Y., Kamijo, A., Yumura, I., Tanabe, K., Miyawaki, A. \& Koga, K. (2013). Fermentation of non-sterilized fish biomass with a mixed culture of film-forming yeasts and lactobacilli and its effect on innate and adaptive immunity in mice. Journal of bioscience and bioengineering, 116, 682-687.

Jia, J., Zhou, Y., Lu, J., Chen, A., Li, Y. \& Zheng, G. (2010). Enzymatic hydrolysis of Alaska pollack (Theragra chalcogramma) skin and antioxidant activity of the resulting hydrolysate. Journal of the Science of Food and Agriculture, 90, 635-640.

Jongjareonrak, A., Benjakul, S., Visessanguan, W., Nagai, T. \& Tanaka, M. (2005). Isolation and characterisation of acid and pepsin-solubilised collagens from the skin of Brownstripe red snapper (Lutjanus vitta). Food chemistry, 93, 475-484.

Kadler, K. E., Hill, A. \& Canty-Laird, E. G. (2008). Collagen fibrillogenesis: fibronectin, integrins, and minor collagens as organizers and nucleators. Current opinion in cell biology, 20, 495501.

Kaewdang, O., Benjakul, S., Kaewmanee, T. \& Kishimura, H. (2014). Characteristics of collagens from the swim bladders of yellowfin tuna (Thunnus albacares). Food Chemistry, 155, 264270.

Karim, A. \& Bhat, R. (2009a). Fish gelatin: properties, challenges, and prospects as an alternative to mammalian gelatins. Food hydrocolloids, 23, 563-576. 
Karim, A. A. \& Bhat, R. (2009b). Fish gelatin: properties, challenges, and prospects as an alternative to mammalian gelatins. Food Hydrocolloids, 23, 563-576.

Kim, S.-K. \& Mendis, E. (2006). Bioactive compounds from marine processing byproducts-a review. Food Research International, 39, 383-393.

Kittiphattanabawon, P., Benjakul, S., Visessanguan, W., Nagai, T. \& Tanaka, M. (2005). Characterisation of acid-soluble collagen from skin and bone of bigeye snapper (Priacanthus tayenus). Food chemistry, 89, 363-372.

Kołodziejska, I., Sikorski, Z. E. \& Niecikowska, C. (1999). Parameters affecting the isolation of collagen from squid (Illex argentinus) skins. Food Chemistry, 66, 153-157.

König, H. \& Fröhlich, J. (2017). Lactic acid bacteria. Biology of Microorganisms on Grapes, in Must and in Wine. Springer.

Ledward, D. (2000). Gelatin. Handbook of hydrocolloids, 67-86.

Lethias, C., Cluzel, C., Valcourt, U. \& Exposito, J.-Y. (2010). The Fibrillar Collagen Family. International Journal of Molecular Sciences, 11, 407-426.

Li, D., Mu, C., Cai, S. \& Lin, W. (2009). Ultrasonic irradiation in the enzymatic extraction of collagen. Ultrasonics sonochemistry, 16, 605-609.

Lin, Y.-K., Lin, T.-Y. \& Su, H.-P. (2011). Extraction and characterisation of telopeptide-poor collagen from porcine lung. Food Chemistry, 124, 1583-1588.

Liu, D., Wei, G., Li, T., Hu, J., Lu, N., Regenstein, J. M. \& Zhou, P. (2015). Effects of alkaline pretreatments and acid extraction conditions on the acid-soluble collagen from grass carp (Ctenopharyngodon idella) skin. Food Chemistry, 172, 836-843.

Mahboob, S. (2015). Isolation and characterization of collagen from fish waste material-skin, scales and fins of Catla catla and Cirrhinus mrigala. Journal of food science and technology, 52, 4296-4305.

Muralidharan, N., Shakila, R. J., Sukumar, D. \& Jeyasekaran, G. (2013). Skin, bone and muscle collagen extraction from the trash fish, leather jacket (Odonus niger) and their characterization. Journal of food science and technology, 50, 1106-1113.

Nagai, T., Araki, Y. \& Suzuki, N. (2002). Collagen of the skin of ocellate puffer fish (Takifugu rubripes). Food chemistry, 78, 173-177.

Nagai, T. \& Suzuki, N. (2000). Isolation of collagen from fish waste material—skin, bone and fins. Food Chemistry, 68, 277-281. 
Nagai, T., Worawattanamateekul, W., Suzuki, N., Nakamura, T., Ito, T., Fujiki, K., Nakao, M. \& Yano, T. (2000). Isolation and characterization of collagen from rhizostomous jellyfish (Rhopilema asamushi). Food Chemistry, 70, 205-208.

Nagai, T., Yamashita, E., Taniguchi, K., Kanamori, N. \& Suzuki, N. (2001). Isolation and characterisation of collagen from the outer skin waste material of cuttlefish (Sepia lycidas). Food chemistry, 72, 425-429.

Nalinanon, S., Benjakul, S., Visessanguan, W. \& Kishimura, H. (2007). Use of pepsin for collagen extraction from the skin of bigeye snapper (Priacanthus tayenus). Food Chemistry, 104, 593-601.

Nalinanon, S., Benjakul, S., Visessanguan, W. \& Kishimura, H. (2008). Tuna pepsin: characteristics and its use for collagen extraction from the skin of threadfin bream (Nemipterus spp.). Journal of Food Science, 73.

Newton, K. \& Gill, C. (1978). The development of the anaerobic spoilage flora of meat stored at chill temperatures. Journal of Applied Bacteriology, 44, 91-95.

Ninan, G., Joseph, J. \& Aliyamveettil, Z. A. (2014). A comparative study on the physical, chemical and functional properties of carp skin and mammalian gelatins. Journal offood science and technology, 51, 2085-2091.

Ogawa, M., Portier, R. J., Moody, M. W., Bell, J., Schexnayder, M. A. \& Losso, J. N. (2004). Biochemical properties of bone and scale collagens isolated from the subtropical fish black drum (Pogonia cromis) and sheepshead seabream (Archosargus probatocephalus). Food chemistry, 88, 495-501.

Ólafsdóttir, G. (2003). Networking in Fisheries Research. Nordic Council of Ministers.

Pang, S. C. F. (2016). Extraction of Collagen from Fish Wastes, Optimization and Characterization. UTAR.

Paschalis, E., Verdelis, K., Doty, S., Boskey, A., Mendelsohn, R. \& Yamauchi, M. (2001). Spectroscopic characterization of collagen cross-links in bone. Journal of Bone and Mineral Research, 16, 1821-1828.

Pati, F., Adhikari, B. \& Dhara, S. (2010). Isolation and characterization of fish scale collagen of higher thermal stability. Bioresource technology, 101, 3737-3742.

Raa, J., Gildberg, A. \& Olley, J. N. (1982). Fish silage: a review. Critical Reviews in Food Science \& Nutrition, 16, 383-419. 
Ruddle, K. \& Ishige, N. (2010). On the origins, diffusion and cultural context of fermented fish products in Southeast Asia. Globalization, Food and Social Identities in the Asia Pacific

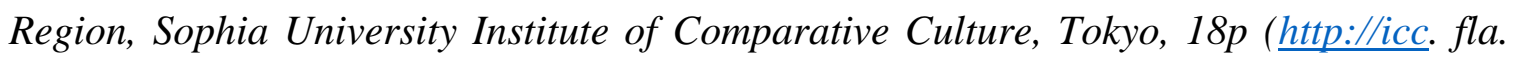
sophia. ac.jp/global\% 20food\% 20papers/html/ruddle_ishige. html).

Saisithi, P. (1994). Traditional fermented fish: fish sauce production. Fisheries processing. Springer.

Saito, Y., Kitamura, H., Hijikata, A., Tomizawa-Murasawa, M., Tanaka, S., Takagi, S., Uchida, N., Suzuki, N., Sone, A. \& Najima, Y. (2010). Identification of therapeutic targets for quiescent, chemotherapy-resistant human leukemia stem cells. Science translational medicine, 2, 17ra9-17ra9.

Sandhu, S. V., Gupta, S., Bansal, H. \& Singla, K. (2012). Collagen in health and disease. J Orofac Res, 2, 153-59.

Santos, M. H., Silva, R. M., Dumont, V. C., Neves, J. S., Mansur, H. S. \& Heneine, L. G. D. (2013). Extraction and characterization of highly purified collagen from bovine pericardium for potential bioengineering applications. Materials Science and Engineering: C, 33, 790-800.

Schmidt, M., Dornelles, R., Mello, R., Kubota, E., Mazutti, M., Kempka, A. \& Demiate, I. (2016). Collagen extraction process. International Food Research Journal, 23.

Schrieber, R. \& Gareis, H. (2007). Gelatine handbook: theory and industrial practice, John Wiley \& Sons.

Scott, R. \& Sullivan, W. C. (2008). Ecology of fermented foods. Human Ecology Review, 25-31.

Shen, J.-W., Wu, T., Wang, Q. \& Pan, H.-H. (2008). Molecular simulation of protein adsorption and desorption on hydroxyapatite surfaces. Biomaterials, 29, 513-532.

Sibilla, S., Godfrey, M., Brewer, S., Budh-Raja, A. \& Genovese, L. (2015). An overview of the beneficial effects of hydrolysed collagen as a nutraceutical on skin properties: Scientific background and clinical studies. The Open Nutraceuticals Journal, 8.

Silva, T. H., Moreira-Silva, J., Marques, A. L., Domingues, A., Bayon, Y. \& Reis, R. L. (2014). Marine origin collagens and its potential applications. Marine drugs, 12, 5881-5901.

Singh, P., Benjakul, S., Maqsood, S. \& Kishimura, H. (2011). Isolation and characterisation of collagen extracted from the skin of striped catfish (Pangasianodon hypophthalmus). Food chemistry, 124, 97-105. 
Skierka, E. \& Sadowska, M. (2007). The influence of different acids and pepsin on the extractability of collagen from the skin of Baltic cod (Gadus morhua). Food Chemistry, 105, 1302-1306.

Stanbury, P. F., Whitaker, A. \& Hall, S. J. (2013). Principles offermentation technology, Elsevier.

Subhan, F., Ikram, M., Shehzad, A. \& Ghafoor, A. (2015). Marine collagen: an emerging player in biomedical applications. Journal of food science and technology, 52, 4703-4707.

Tamilmozhi, S., Veeruraj, A. \& Arumugam, M. (2013). Isolation and characterization of acid and pepsin-solubilized collagen from the skin of sailfish (Istiophorus platypterus). Food Research International, 54, 1499-1505.

Tanasupawat, S., Taprig, T., Akaracharanya, A. \& Visessanguan, W. (2011). Characterization of Virgibacillus strain TKNR13-3 from fermented shrimp paste (ka-pi) and its protease production. African Journal of Microbiology Research, 5, 4714-4721.

Tang, L., Chen, S., Su, W., Weng, W., Osako, K. \& Tanaka, M. (2015). Physicochemical properties and film-forming ability of fish skin collagen extracted from different freshwater species. Process Biochemistry, 50, 148-155.

Torres-Llanez, M., Vallejo-Cordoba, B., Díaz-Cinco, M., Mazorra-Manzano, M. \& GonzalezCordova, A. (2006). Characterization of the natural microflora of artisanal Mexican Fresco cheese. Food control, 17, 683-690.

Tylingo, R., Gorczyca, G., Mania, S., Szweda, P. \& Milewski, S. (2016). Preparation and characterization of porous scaffolds from chitosan-collagen-gelatin composite. Reactive and Functional Polymers, 103, 131-140.

Vrana, N. E., Builles, N., Justin, V., Bednarz, J., Pellegrini, G., Ferrari, B., Damour, O., Hulmes, D. J. \& Hasirci, V. (2008). Development of a reconstructed cornea from collagenchondroitin sulfate foams and human cell cultures. Investigative ophthalmology \& visual science, 49, 5325-5331.

Wang, L., An, X., Xin, Z., Zhao, L. \& Hu, Q. (2007). Isolation and Characterization of Collagen from the Skin of Deep-Sea Redfish (Sebastes mentella). Journal of Food Science, 72.

Wang, L., Liang, Q., Chen, T., Wang, Z., Xu, J. \& Ma, H. (2014). Characterization of collagen from the skin of Amur sturgeon (Acipenser schrenckii). Food Hydrocolloids, 38, 104-109.

Wong, R. J., Aguilar, M., Cheung, R., Perumpail, R. B., Harrison, S. A., Younossi, Z. M. \& Ahmed, A. (2015). Nonalcoholic steatohepatitis is the second leading etiology of liver 
disease among adults awaiting liver transplantation in the United States. Gastroenterology, $148,547-555$.

Woo, J.-W., Yu, S.-J., Cho, S.-M., Lee, Y.-B. \& Kim, S.-B. (2008). Extraction optimization and properties of collagen from yellowfin tuna (Thunnus albacares) dorsal skin. Food Hydrocolloids, 22, 879-887.

Yamaguchi, K. (2002). Bovine spongiform encephalopathy and People. Tokyo: Iwanami Press.

Yang, H. \& Shu, Z. (2014). The extraction of collagen protein from pigskin. Journal of chemical and pharmaceutical research, 6, 683-687.

Zhang, J., Li, L., Kim, S.-H., Hagerman, A. E. \& Lü, J. (2009). Anti-cancer, anti-diabetic and other pharmacologic and biological activities of penta-galloyl-glucose. Pharmaceutical research, 26, 2066-2080.

Zhang, P., Liu, X., Zhu, Y., Chen, S., Zhou, D. \& Wang, Y. (2013). Honokiol inhibits the inflammatory reaction during cerebral ischemia reperfusion by suppressing NF- $\mathrm{B}$ activation and cytokine production of glial cells. Neuroscience letters, 534, 123-127.

Zhang, Y., Liu, W., Li, G., Shi, B., Miao, Y.\& Wu, X. (2007). Isolation and partial characterization of pepsin-soluble collagen from the skin of grass carp (Ctenopharyngodon idella). Food chemistry, 103, 906-912. 